\title{
AN OVERVIEW OF A LEADER JOURNAL IN THE FIELD OF TRANSPORT: A BIBLIOMETRIC ANALYSIS OF “COMPUTER-AIDED CIVIL AND INFRASTRUCTURE ENGINEERING” FROM 2000 TO 2019
}

\author{
Xinxin WANG ${ }^{1}$, Zeshui XU ${ }^{2}$, Zijing $\mathrm{GE}^{3}$, \\ Edmundas Kazimieras ZAVADSKAS ${ }^{4}$, Paulius SKAČKAUSKAS ${ }^{5 \#}$ \\ 1,2,3Business School, Sichuan University, Chengdu, China \\ ${ }^{4}$ Institute of Sustainable Construction, Vilnius Gediminas Technical University, Vilnius, Lithuania \\ ${ }^{5}$ Dept of Mobile Machinery and Railway Transport, Vilnius Gediminas Technical University, Vilnius, Lithuania
}

Received 26 September 2020; accepted 8 November 2020

\begin{abstract}
Computer-Aided Civil And Infrastructure Engineering (CACAIE) is an international journal, and the first documents was published from 1980. This article is to make an overview based on bibliometric analysis to celebrate the 35th anniversary of CACAIE till 2019. At present, 1045 publications can be indexed in the Clarivate Analytics Web of Science (WoS) from 2000 to 2019, and we explore the characteristics of these publications by bibliometric methods and tools (VOSviewer and CiteSpace). First, the fundamental information of publications is given with the help of some bibliometric indicators, such as the number of citations and $h$-index. According to high-citing and high-cited publications, we analyse that who pays closer attention to the journal and what the journal most focuses on considering sources, countries/regions, institutions and authors. After that, the influential countries/regions and references are presented, and collaboration networks are given to show the relationship among countries/regions, institutions and authors. In order to understand the development trends and hot topics, co-occurrence analysis and timeline view of keywords are made to be visual. In addition, publications in four fields - Construction \& Building Technology; Engineering, Civil; Transportation Science \& Technology; Computer Science, Interdisciplinary Applications - that CACAIE refers are summarized, and further discussions are made for the journal and scholars. Finally, some main findings are concluded according to all analysis. This article provides a certain reference for scholars and journals to further research and promote the scientific-technological progress.
\end{abstract}

Keywords: Computer-Aided Civil and Infrastructure Engineering, journal, article, bibliometric analysis, collaboration networks, development trends, hot topics.

\section{Introduction}

Computer-Aided Civil And Infrastructure Engineering (CACAIE) is an international authority journal (print ISSN: 1093-9687 / online ISSN: 1467-8667) that is intended to act as a bridge between advances being made in computer technology and civil and infrastructure engineering. As introduced in the homepage of the journal (https:// onlinelibrary.wiley.com/journal/14678667), CACAIE calls for bridge, construction, environmental, highway, geotechnical, structural, transportation, and water resources engineering, and management of infrastructure systems. The journal was found in 1986, and 2019 celebrates the 35th anniversary. Its founder and Editor-in-Chief is Prof. $\mathrm{H}$. Adeli, who is an excellent generator of ideas and a
Clarivate Analytics Highly Cited Researcher in three categories of Computer Science, Engineering, and Cross-Field. CACAIE has been indexed in Clarivate Analytics Science Citation Index Expanded (SCIE) database since 2000 with an impact factor of 8.552 by Clarivate Analytics Journal Citation Reports (JCR 2019). In Clarivate Analytics Web of Science (WoS), CACAIE has 1045 publications from 2000 to 2019, and has ranked the first in three categories for many years, i.e., 1/63 in Construction \& Building Technology, 1/134 in Engineering, Civil and 1/36 in Transportation Science \& Technology, and 5/109 academic journals in the field of Computer Science, Interdisciplinary Applications. Absolutely, CACAIE is a long-time leader and ex-

\footnotetext{
${ }^{*}$ Corresponding author. E-mail: xuzeshui@263.net

\#Managing Editor of the TRANSPORT - the manuscript was handled by one of the Editors, who made all decisions related to the manuscript (including the choice of referees and the ultimate decision on the revision and publishing).
}

Copyright (C) 2020 The Author(s). Published by Vilnius Gediminas Technical University

This is an Open Access article distributed under the terms of the Creative Commons Attribution License (http://creativecommons.org/licenses/by/4.0/), which permits unrestricted use, distribution, and reproduction in any medium, provided the original author and source are credited. 
emplary journal in the categories above, and the impact of it has been significant. In addition, the journal has high recognition in the academic community. For example, Prof. E. K. Zavadskas, said that CACAIE has remained the best journal to be an example and has elevated the profile of the entire civil engineering field in bibliometrics (Zavadskas 2020). Therefore, CACAIE has been recognized by scholars and other journals in the same research fields because of publications during past 35 years, and it is meaningful to make an overview about CACAIE systematically and intuitively based on bibliometric methods.

Bibliometrics is a statistical analysis of publications, as well as a branch of intelligence science. Bibliometric methods are always used to provide quantitative analysis of academic literature, and they are effective tools to reveal the characteristics and the merits of a certain journal or a given research direction (Shang et al. 2015; White 2018). For one thing, bibliometric methods can explore the development of a journal or a research direction about features, keywords, hot topics with the help of bibliometric indicators and tools. For another, it is a complex discipline with the extensive combination of information science, philology and statistics for a journal or a specific field (He et al. 2017). Many research fields use bibliometric methods to explore the impact of their field, the impact of a set of researchers, or the impact of a particular article. Bibliometrics also has a wide range of other applications, such as in descriptive linguistics, the development of thesauri, and evaluation of reader usage. Up to now, some research areas, like sustainable energy (Hache, Palle 2019), uncertain group decision-making (Wang et al. 2021) and supply chain of renewable energy (Azevedo et al. 2019), have been studied by bibliometric analysis. In addition, it seems to be popular to analyse journals comprehensively so that scholars and editors better understand the trends and features, and some top journals have been researched, such as: The Baltic Journal of Road and Bridge Engineering (Zhou et al. 2020), Transport (Zhou et al. 2019), Journal of Civil Engineering and Management (Yu et al. 2019), IEEE Transaction on Fuzzy Systems (Yu et al. 2018), Information Sciences (Yu et al. 2017), and European Journal of Operational Research (Laengle et al. 2017).

Due to that CACAIE is a top journal in four fields attracted by many scholars and has been published documents for 35 years, a bibliometric analysis of the journal is necessary and meaningful to overview the characteristics and research contents of publications. Considering that publications in the journal are indexed in the WoS since 2000 , in this article, we make an overview of CACAIE based on bibliometric analysis from 2000 to 2019 , and the main contributions are as follows:

- characteristics of publications in CACAIE are analysed to describe the inner structure and development trend of the journal. Specifically, fundamental information of publications is provided including the type, the annual trends of publications and citations. The concern issues are presented that who pays more attention to CACAIE and what the journal more focuses on. Furthermore, the most influential countries/regions and references are obtained during past 20 years;

- landscape analysis is given to show the relationships of items in publications by collaboration networks at levels of country/region, institution and authors, and co-occurrence and timeline view of keywords;

- researches in CACAIE are summarized for scholars to further study effectively and scientifically in relevant fields, i.e., Construction \& Building Technology; Engineering, Civil; Transportation Science \& Technology; Computer Science, Interdisciplinary Applications;

- further discussions are addressed from three aspects based on the characteristics and research contents.

The rest of this article is organized as follows. Section 1 illustrates data source and bibliometric methods. In Section 2, the characteristics of publications in the journal are analysed about fundamental information, concern issues, influential countries/regions and references, collaboration networks, co-occurrence and timeline view of keywords. Section 3 summarizes the research in relevant fields. In Section 4, some discussions are provided from three aspects based on above-mentioned analysis. The last section ends the article with some conclusions.

\section{Data source and bibliometric methods}

WoS is one of the popular databases in academics, owned by the Clarivate Analytics, and has provided leading journals available and detailed information about publications around the world (Falagas et al. 2008). Since the first publication of CACAIE indexed in WoS is in 2000, we make an overview of publications in the journal from 2000 to 2019 for 20 years. As a result, 1045 publications, indexed in SCIE or Clarivate Analytics Social Sciences Citation Index (SSCI), are available and derived to be further analysed. The data are exported in plain text format and Comma-Separated Values (CSV) format with full records and reference information.

In order to analyse the characteristics of publications in the journal scientifically and clearly, we use bibliometric methods from two aspects. On the one hand, we evaluate the productivity and influence of publications by recognized bibliometric indicators, such as $h$-index (Hsieh, Chang 2009), Number of Publications (NP), Number of Citations (NC) and Average Citations (AC) per publication. On the other hand, CiteSpace (Chen 2006) and VOSviewer (Stopar, Bartol 2019) are chosen to make visualized analysis of publications in the journal, because visualization is an important technique to intuitively see the structure and the trend of a research field or a journal in bibliometric analysis (Cobo et al. 2011). At present, CiteSpace and VOSviewer have been widely applied in many areas (Chan, Kuehl 2019; Chen, Liu 2020; Kamdem et al. 2019; Wang et al. 2019; Zhou et al. 2019) because of mapping visualization capability and powerful user graphic-interface. Therefore, we use them to present the relation of items of publications in CACAIE. 
In order to show the features comprehensibly, we make bibliometric analysis from multiple aspects, and bibliometric methods are used in this article as follows:

- co-citation analysis - it measures the proximity degree about references or sources or authors, to identify the research field;

- burst detection analysis - it can reflect the emerging trends and most popular items (references/sources/ authors) that attracted by scholars;

- co-authorship analysis - according to gather information from perspective of country/region or institution or author, collaboration network is obtained to represent the NP co-authored by at least two ones;

- co-occurrence analysis - in terms of keywords, it shows the number of keywords that occur together among publications;

- timeline analysis - combined with timeline, the developing tendency of keywords in the journal is revealed during a certain time.

\section{Characteristics of publications in the journal}

With the development of 20 years, publications in CACAIE have presented some characteristics and trends at various levels. According to bibliometric analysis and visualization tools, i.e., VOSviewer and CiteSpace, general features and science mapping results of publications are obtained from multiple aspects, such as concerns, citations, collaborations and timeline view of keywords.

\subsection{Fundamental information of publications}

In the WoS, there are 1045 publications of CACAIE from 2000 to 2019 with 7 types, i.e., article, editorial material, review, correction, biographical item, proceedings article and early access. It is noted that proceedings article and early access also belong to one of the other 5 types. Among 1045 publications, except for proceedings article and early access, article accounts for a large proportion $(973,93.11 \%)$, followed by editorial material $(60,5.74 \%)$ and review $(9,0.86 \%)$, shown in Figure 1.

Figure 2 shows the trends of the NP and the NC in the journal over 20 years. In Figure $2 \mathrm{a}$, on the whole, NP presents a smooth and slow upward trend. In particular, NP levels off at about 40 from 2000 to 2005, and the number grows from a dozen or so to perhaps 50 from 2006 to 2014. In the past five years, NP has been further increased, especially in 2019 with 99 publications. In Figure $2 \mathrm{~b}, \mathrm{NC}$ shows a steady upward trend, and it reaches 4036 in 2019. Combining the development trends of NP and NC, CACAIE focuses on the quality of manuscripts, and controls the NP each year. Besides, more and more scholars have paid much attention to the journal because of higher citations.

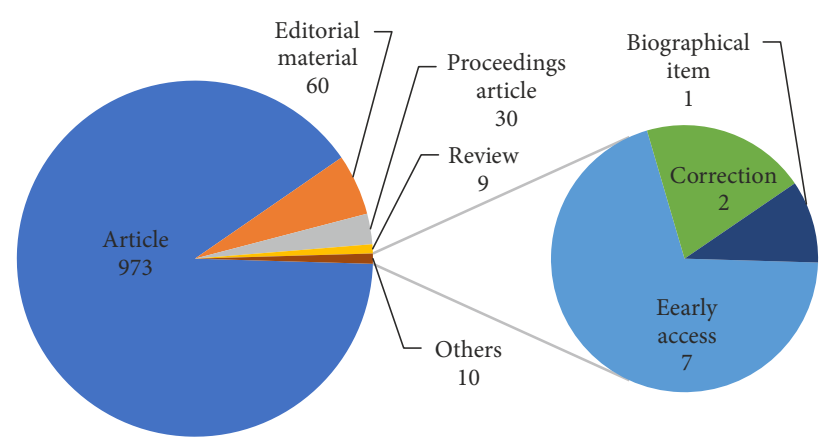

Figure 1. The type distribution of publications in the CACAIE

a)

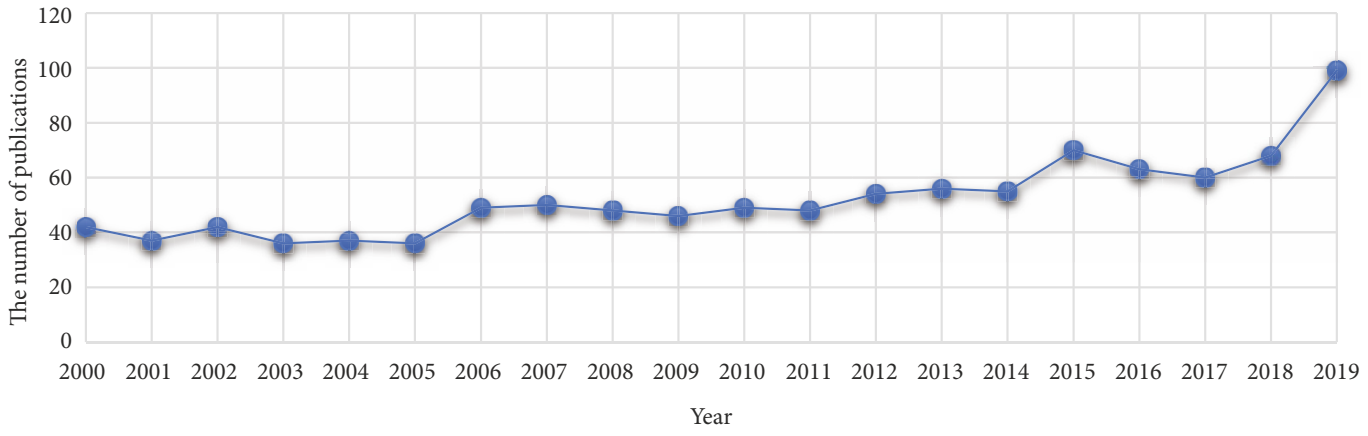

b)

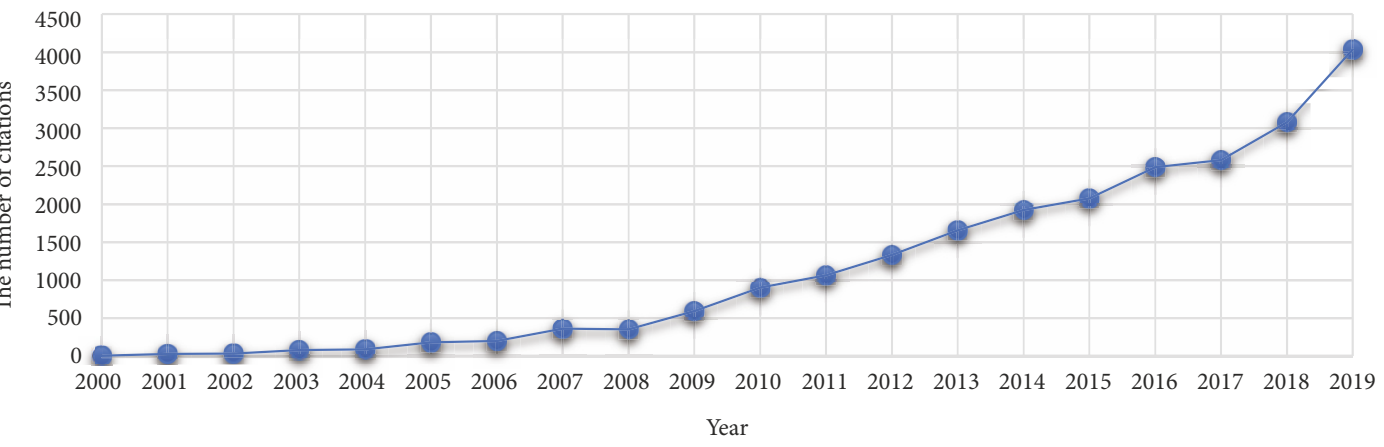

Figure 2. The NP (a) and NC (b) per year from 2000 to 2019 in the CACAIE 


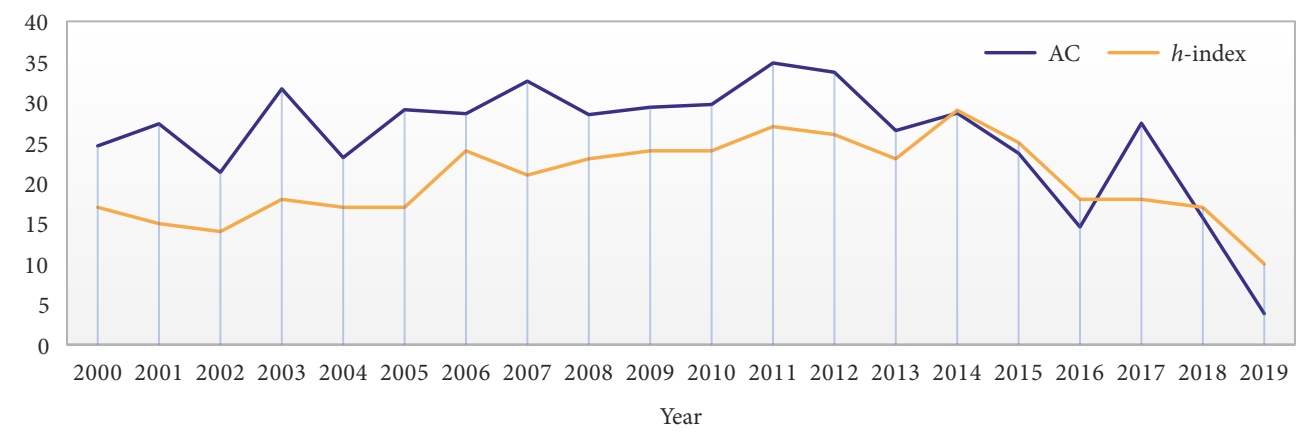

Figure 3. The trends of AC and $h$-index of publications from 2000 to 2019 in the CACAIE

The AC and $h$-index in each year reveal the recognition and influence of publications in the journal. Figure 3 shows the trends of the AC and $h$-index of publications from 2000 to 2019. As far as AC, it is always greater than 20 from 2000 to 2015 , and the highest number is 34.85 in 2011, followed by 33.72 in 2012, 32.6 in 2007 and 31.64 in 2003. It indicates that publications in these years are more valuable and popular. On the other hand, the lowest number is 3.85 in 2019, followed by 14.57 in 2016 and 15.69 in 2018. The reason may be that publications need time to be widely recognized and cited instead of no excellent contributions (Pilkington, Meredith 2009). $h$-index is another index to measure both the productivity and citation impact of the published work of a scholar. Compared with AC, $h$-index has a smaller range from 2000 to 2019. Specifically, 2014 received the highest $h$-index, i.e., 29. The second and the third are 27 and 25 in 2011,
2015, respectively. Therefore, publications in 2011, 2012 and 2014 are most cited and recognized combined with $\mathrm{AC}$ and $h$-index.

\subsection{Who pays attention to CACAIE and what the journal focuses on}

Citation is one of the forms to pay attention to the journal. As for 1045 publications in CACAIE from 2000 to 2019, the total citation frequency is 25679 , and the frequency is 20812 after removing the self-citation in the WoS. The $h$-index is 70 , and the $\mathrm{AC}$ is 24.57 , indicating that many researchers around the world have been great interested in the journal. Table 1 lists the top 10 popular sources, countries/regions, institutions and authors of cited publications in the CACAIE.

In Table 1, the most citing sources are all top journals that top 8 sources are JCR Q1 journals, and the last two are

Table 1. Top 10 sources/countries (regions)/institutions/authors of cited publications in the CACAIE

\begin{tabular}{|c|c|c|c|c|c|c|c|c|}
\hline \multirow[b]{2}{*}{ Rank } & \multicolumn{2}{|l|}{ Top 10 sources } & \multicolumn{2}{|c|}{ Top 10 countries (regions) } & \multicolumn{2}{|c|}{ Top 10 institutions } & \multicolumn{2}{|c|}{ Top 10 authors } \\
\hline & Source & $\begin{array}{c}\text { No of } \\
\text { citations }\end{array}$ & $\begin{array}{l}\text { Country } \\
\text { (region) }\end{array}$ & $\begin{array}{c}\text { No of } \\
\text { citations }\end{array}$ & Institution & $\begin{array}{c}\text { No of } \\
\text { citations }\end{array}$ & Author & $\begin{array}{c}\text { No of } \\
\text { citations }\end{array}$ \\
\hline 1 & $\begin{array}{l}\text { Computer-Aided Civil } \\
\text { and Infrastructure } \\
\text { Engineering }\end{array}$ & 14141 & US & 37745 & $\begin{array}{l}\text { Ohio State } \\
\text { University }\end{array}$ & 5273 & H. Adeli & 5160 \\
\hline 2 & $\begin{array}{l}\text { Automation in } \\
\text { Construction }\end{array}$ & 4474 & China & 21040 & $\begin{array}{l}\text { University of } \\
\text { Illinois Urbana- } \\
\text { Champaign }\end{array}$ & 2783 & Y. H. Wang & 861 \\
\hline 3 & $\begin{array}{l}\text { Transportation Research } \\
\text { Part C: Emerging } \\
\text { Technologies }\end{array}$ & 3905 & Canada & 7443 & $\begin{array}{l}\text { Hong Kong } \\
\text { Polytechnic } \\
\text { University }\end{array}$ & 2747 & D. M. Frangopol & 768 \\
\hline 4 & $\begin{array}{l}\text { Mechanical Systems and } \\
\text { Signal Processing }\end{array}$ & 2247 & England & 6428 & Rice University & 2137 & O. Büyüköztürk & 765 \\
\hline 5 & \begin{tabular}{|l|} 
Transportation Research \\
Part B: Methodological \\
\end{tabular} & 2181 & Spain & 5579 & Tongji University & 1736 & E. I. Vlahogianni & 732 \\
\hline 6 & Engineering Structures & 2141 & Australia & 5124 & $\begin{array}{l}\text { University of } \\
\text { Maryland }\end{array}$ & 1576 & M. G. Karlaftis & 730 \\
\hline 7 & $\begin{array}{l}\text { Journal of Computing } \\
\text { in Civil Engineering }\end{array}$ & 1892 & South Korea & 4350 & $\begin{array}{l}\text { National } \\
\text { Technical } \\
\text { University of } \\
\text { Athens }\end{array}$ & 1572 & Y.-J. Cha & 718 \\
\hline 8 & $\begin{array}{l}\text { Integrated Computer- } \\
\text { Aided Engineering }\end{array}$ & 1801 & Italy & 3864 & $\begin{array}{l}\text { Texas A\&M } \\
\text { University }\end{array}$ & 1559 & Y. F. Ouyang & 625 \\
\hline 9 & $\begin{array}{l}\text { Structure and } \\
\text { Infrastructure } \\
\text { Engineering }\end{array}$ & 1447 & Taiwan & 3454 & $\begin{array}{l}\text { Georgia Institute } \\
\text { of Technology }\end{array}$ & 1394 & U. R. Acharya & 584 \\
\hline 10 & $\begin{array}{l}\text { Journal of Structural } \\
\text { Engineering }\end{array}$ & 1423 & Germany & 2593 & $\begin{array}{l}\text { University of } \\
\text { California, } \\
\text { Berkeley }\end{array}$ & 1381 & W. S. Travis & 537 \\
\hline
\end{tabular}


JCR Q2 journals. It indicates that CACAIE requires high quality for publications, and can provide valuable reference for scholars who submit manuscript to other journals in the same research fields. As far as countries/regions, the US ranks the first, followed by China, Canada, England and Spain. In the top 10 institutions, 7 of them are from the US, i.e., Ohio State University, University of Illinois Urbana-Champaign, Rice University, University of Maryland, Texas A\&M University, Georgia Institute of Technology, and University of California, Berkeley. Two of the top 5 institutions are from China, i.e., Hong Kong Polytechnic University and Tongji University. It shows that scholars in the US and China pay more attention to CACAIE, such as H. Adeli, Y. H. Wang and D. M. Frangopol.

On the other hand, what is the journal CACAIE most focuses on? From 2000 to 2019, 1045 publications cocitation cited 27735 references, 10070 sources and 17676 authors. Table 2 presents the top 10 most cited references, sources and authors of publications in CACAIE and their citations.

Considering three aspects comprehensively, i.e., reference, source and author, the research of $\mathrm{H}$. Adeli is the most recognized in this field with 1225 citations presented absolute influence, followed by X. Jiang with 473 citations, and K. C. Sarma with 235 citations. In addition, 9 of top 10 references belong to these three authors. Specifically, half of the top 10 references are written by X. Jiang, and the most cited reference with 93 citations published in Journal of Structural Engineering is written by H. Adeli in 2006. As far as the sources, CACAIE is the most cited journal and is comfortably ahead of other sources; the reason may be that it is the top one journal in three fields of the WoS, i.e., Construction \& Building Technology; Engineering, Civil; Transportation Science \& Technology.

In order to visualize the cited references/sources/authors clearly and further reflect the surging frequency of citations, the co-citation analysis and burst detection analysis of publications in CACAIE are made by CiteSpace. Figure 4 shows the cited references/sources/authors networks, and labels the most cited ones. It is noted that a node represents a reference/source/author, and the size of the node indicates the NC with which the reference/ source/author is cited.

According to the size of the nodes in Figure 4, the gap is smaller in the cited references network, while the situations are more prominent in the cited sources and authors networks. Specifically, CACAIE and H. Adeli are very excellent as a cited sources and cited author, respectively. In order to further show the dynamic changes of citations, Tables 3 and 4 list the top 12 strongest citation bursts of cited references/authors by burst detection analysis from 2000 to 2019 , respectively.

As for cited references (Table 3), Marano et al. (2011) has the maximum burst strength (13.2183), followed by Adeli and Jiang $(2006,2009)$. It indicates that these references have greatly attracted the attention of scholars, and are cited for many times during a certain period. In addi- a)

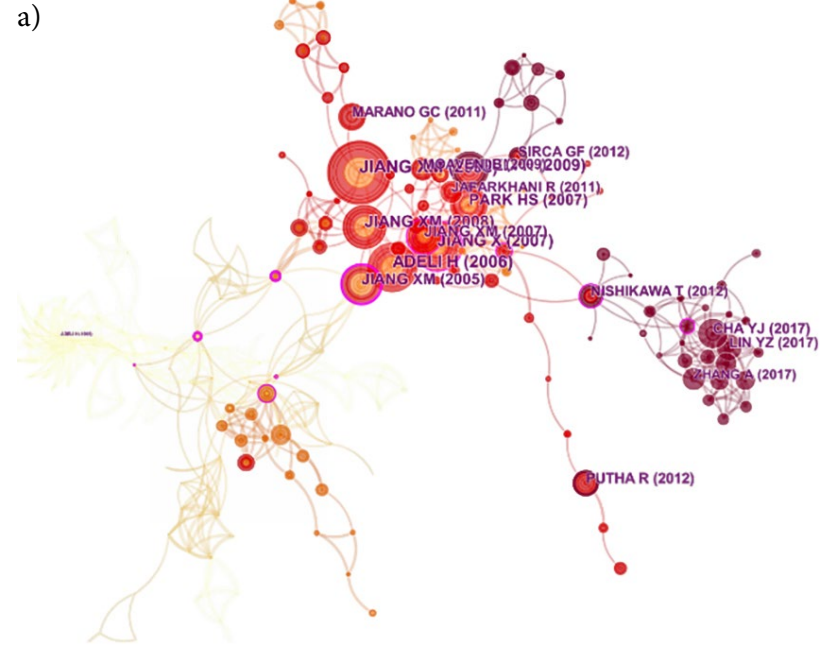

b)

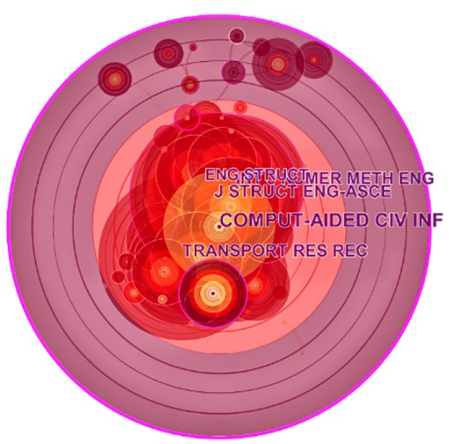

c)

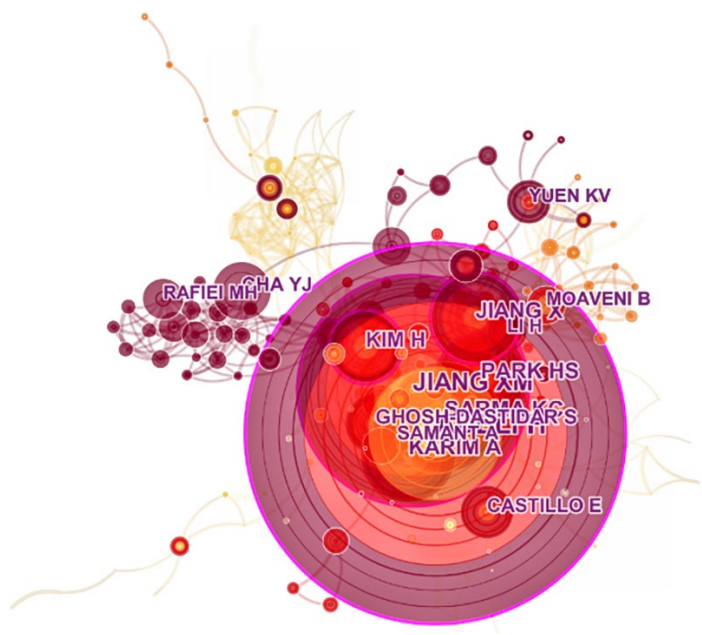

Figure 4. The cited references/sources/authors networks of publications in the journal: a - the cited references network; b - the cited sources network; $\mathrm{c}$ - the cited authors network

tion, Adeli and Jiang (2006) has the longest citation burst duration with 7 years from 2008 to 2014, showing that it has made a far-reaching impact. There are three references that the end time is 2019, i.e., Amézquita-Sánchez and Adeli (2016), Cha and Büyüköztürk (2015), and Yuen and $\mathrm{Mu}$ (2015). It reflects that they may be hot research direction or topics to some extent. 
Table 2. Top 10 cited references/sources/authors of publications in the CACAIE

\begin{tabular}{|c|c|c|c|c|c|c|}
\hline \multirow[b]{2}{*}{ Rank } & \multicolumn{2}{|l|}{ Top 10 references } & \multicolumn{2}{|l|}{ Top 10 sources } & \multicolumn{2}{|c|}{ Top 10 authors } \\
\hline & Reference (title, journal, author(s)) & $\begin{array}{c}\text { No of } \\
\text { citations }\end{array}$ & Sources & $\begin{array}{c}\text { No of } \\
\text { citations }\end{array}$ & Author & $\begin{array}{l}\text { No of } \\
\text { citations }\end{array}$ \\
\hline 1 & $\begin{array}{l}\text { Dynamic fuzzy wavelet neural network model } \\
\text { for structural system identification, Journal of } \\
\text { Structural Engineering } \\
\text { Adeli, Jiang (2006) }\end{array}$ & 93 & $\begin{array}{l}\text { Computer-Aided Civil } \\
\text { and Infrastructure } \\
\text { Engineering }\end{array}$ & 4906 & H. Adeli & 1225 \\
\hline 2 & $\begin{array}{l}\text { Neuro-genetic algorithm for non-linear active } \\
\text { control of structures, International Journal for } \\
\text { Numerical Methods in Engineering } \\
\text { Jiang, Adeli (2008) }\end{array}$ & 88 & $\begin{array}{l}\text { Transportation Research } \\
\text { Record: Journal of the } \\
\text { Transportation Research } \\
\text { Board }\end{array}$ & 858 & X. Jiang & 473 \\
\hline 3 & $\begin{array}{l}\text { Dynamic wavelet neural network for nonlinear } \\
\text { identification of highrise buildings, Computer- } \\
\text { Aided Civil and Infrastructure Engineering } \\
\text { Jiang, Adeli (2005a) }\end{array}$ & 86 & $\begin{array}{l}\text { Transportation Research } \\
\text { Part B: Methodological }\end{array}$ & 835 & K. C. Sarma & 235 \\
\hline 4 & $\begin{array}{l}\text { Pseudospectra, MUSIC, and dynamic wavelet } \\
\text { neural network for damage detection of highrise } \\
\text { buildings, International Journal for Numerical } \\
\text { Methods in Engineering } \\
\text { Jiang, Adeli (2007) }\end{array}$ & 80 & $\begin{array}{l}\text { Journal of Structural } \\
\text { Engineering }\end{array}$ & 573 & A. Karim & 214 \\
\hline 5 & $\begin{array}{l}\text { A new approach for health monitoring of } \\
\text { structures: terrestrial laser scanning, Computer- } \\
\text { Aided Civil and Infrastructure Engineering } \\
\text { Park et al. (2007) }\end{array}$ & 68 & $\begin{array}{l}\text { Journal of Construction } \\
\text { Engineering and } \\
\text { Management }\end{array}$ & 448 & E. Castillo & 173 \\
\hline 6 & $\begin{array}{l}\text { Dynamic fuzzy wavelet neuroemulator for non- } \\
\text { linear control of irregular building structures, } \\
\text { International Journal for Numerical Methods in } \\
\text { Engineering } \\
\text { Jiang, Adeli (2008) }\end{array}$ & 65 & $\begin{array}{l}\text { International Journal } \\
\text { for Numerical Methods } \\
\text { in Engineering Supports } \\
\text { Engineering }\end{array}$ & 426 & H. Kim & 145 \\
\hline 7 & $\begin{array}{l}\text { Bilevel parallel genetic algorithms for optimization } \\
\text { of large steel structures, Computer-Aided Civil and } \\
\text { Infrastructure Engineering } \\
\text { Sarma, Adeli (2001) }\end{array}$ & 60 & $\begin{array}{l}\text { Transportation Research } \\
\text { Part C: Emerging } \\
\text { Technologies }\end{array}$ & 415 & H. S. Park & 120 \\
\hline 8 & $\begin{array}{l}\text { Bayesian wavelet methodology for structural } \\
\text { damage detection, Structural Control and Health } \\
\text { Monitoring } \\
\text { Jiang, Mahadevan (2008) }\end{array}$ & 59 & Engineering Structures & 406 & M. N. Rafiei & 118 \\
\hline 9 & $\begin{array}{l}\text { Distributed genetic algorithm for structural } \\
\text { optimization, Journal of Aerospace Engineering } \\
\text { Adeli, Kumar (1995) }\end{array}$ & 59 & $\begin{array}{l}\text { Journal of Transportation } \\
\text { Engineering }\end{array}$ & 376 & K. V. Yuen & 117 \\
\hline 10 & $\begin{array}{l}\text { Intelligent Infrastructure: Neural Networks, } \\
\text { Wavelets, and Chaos Theory for Intelligent } \\
\text { Transportation Systems and Smart Structures } \\
\text { Adeli, Jiang (2009) }\end{array}$ & 57 & $\begin{array}{l}\text { Automation in } \\
\text { Construction }\end{array}$ & 363 & Y.-J. Cha & 114 \\
\hline
\end{tabular}

As far as cited authors (Table 4), Y.-J. Cha on the top of the list with the maximum burst strength (23.1668), indicating that he has a great influence in the research field since 2016. D. Goldberg has the longest citation duration with 8 years from 2000 to 2007, followed by H. Sohn, K. V. Yuen and A. Stathopoulos. The citation burst of five authors (Y.-J. Cha, J. P. Amézquita-Sánchez, E. Castillo, K. V. Yuen, and Y. Lecun) are close to 2019, representing that they may research hot topics.

Table 5 lists the top 10 strongest cited sources (in CACAIE) from 2000 to 2019. Structural Design of Tall and Special Buildings, providing structural engineers and contractors with a detailed written presentation of innovative structural engineering and construction practices for tall and special buildings, has the strongest strength (15.2537) from 2017 to 2019, followed by IEEE Conference on Computer Vision and Pattern Recognition (12.6888), Nature (12.3238), and Microcomputers in Civil Engineering (11.4798). Genetic Algorithms in Engineering Systems has the longest duration with 8 years from 2000 to 2007 . Microcomputers in Civil Engineering and Genetic Algorithms in Engineering Systems began from 2000, illustrating that publications in CACAIE cited them earlier and explosively. 
Table 3. The top 12 strongest cited references in the CACAIE from 2000 to 2019

\begin{tabular}{|c|c|c|c|c|c|c|}
\hline Rank & Reference (title, journal, author(s)) & Year & Strength & Begin & End & $2000-2019$ \\
\hline 1 & $\begin{array}{l}\text { Modified genetic algorithm for the dynamic identification of } \\
\text { structural systems using incomplete measurements, Computer- } \\
\text { Aided Civil and Infrastructure Engineering } \\
\text { Marano et al. (2011) }\end{array}$ & 2011 & 13.2183 & 2012 & 2015 & 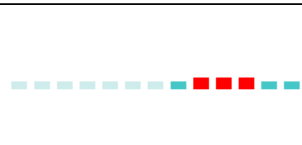 \\
\hline 2 & $\begin{array}{l}\text { Dynamic fuzzy wavelet neural network model for structural } \\
\text { system identification, Journal of Structural Engineering } \\
\text { Adeli, Jiang (2006) }\end{array}$ & 2006 & 12.3399 & 2008 & 2014 & 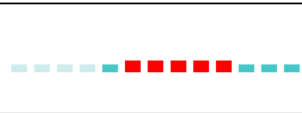 \\
\hline 3 & $\begin{array}{l}\text { Intelligent Infrastructure: Neural Networks, Wavelets, and } \\
\text { Chaos Theory for Intelligent Transportation Systems and Smart } \\
\text { Structures } \\
\text { Adeli, Jiang (2009) }\end{array}$ & 2009 & 12.1216 & 2013 & 2017 & 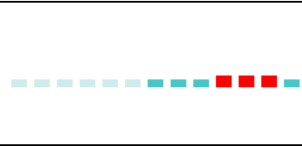 \\
\hline 4 & $\begin{array}{l}\text { Neuro-genetic algorithm for non-linear active control of } \\
\text { structures, International Journal for Numerical Methods in } \\
\text { Engineering } \\
\text { Jiang, Adeli (2008) }\end{array}$ & 2008 & 12.0243 & 2009 & 2014 & 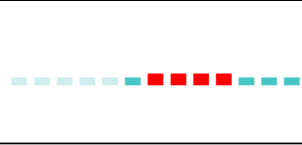 \\
\hline 5 & $\begin{array}{l}\text { Dynamic wavelet neural network model for traffic flow } \\
\text { forecasting, Journal of Transportation Engineering } \\
\text { Jiang, Adeli (2005b) }\end{array}$ & 2005 & 11.3931 & 2007 & 2011 & 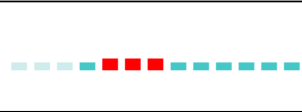 \\
\hline 6 & $\begin{array}{l}\text { Dynamic wavelet neural network for nonlinear identification } \\
\text { of highrise buildings, Computer-Aided Civil and Infrastructure } \\
\text { Engineering } \\
\text { Jiang, Adeli (2005) }\end{array}$ & 2005 & 11.0260 & 2008 & 2013 & 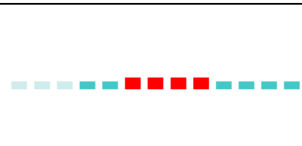 \\
\hline 7 & $\begin{array}{l}\text { Finite element model updating using evolutionary strategy for } \\
\text { damage detection, Computer-Aided Civil and Infrastructure } \\
\text { Engineering } \\
\text { Jafarkhani, Masri (2011) }\end{array}$ & 2011 & 10.5388 & 2012 & 2015 & 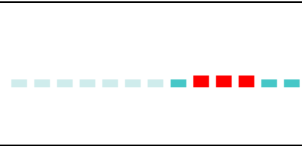 \\
\hline 8 & $\begin{array}{l}\text { Signal processing techniques for vibration-based health } \\
\text { monitoring of smart structures, Archives of Computational } \\
\text { Methods in Engineering } \\
\text { Amézquita-Sánchez, Adeli (2016) }\end{array}$ & 2016 & 9.5323 & 2016 & 2019 & 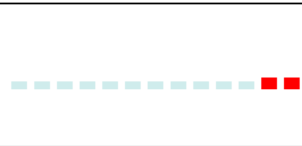 \\
\hline 9 & $\begin{array}{l}\text { Structural damage detection using modal strain energy and } \\
\text { hybrid multiobjective optimization, Computer-Aided Civil and } \\
\text { Infrastructure Engineering } \\
\text { Cha, Büyüköztürk (2015) }\end{array}$ & 2015 & 9.5005 & 2016 & 2019 & 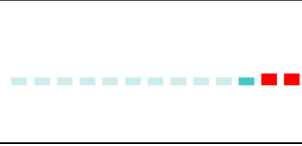 \\
\hline 10 & $\begin{array}{l}\text { Dynamic fuzzy wavelet neuroemulator for non-linear control of } \\
\text { irregular building structures, International Journal for Numerical } \\
\text { Methods in Engineering } \\
\text { Jiang, Adeli (2008) }\end{array}$ & 2008 & 9.4774 & 2009 & 2014 & 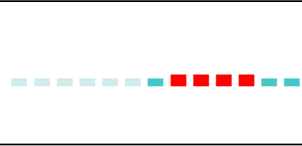 \\
\hline 11 & $\begin{array}{l}\text { A new approach for health monitoring of structures: terrestrial } \\
\text { laser scanning, Computer-Aided Civil and Infrastructure } \\
\text { Engineering } \\
\text { Park et al. (2007) }\end{array}$ & 2007 & 9.3352 & 2011 & 2015 & 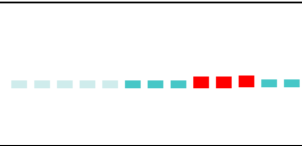 \\
\hline 12 & $\begin{array}{l}\text { Real-time system identification: an algorithm for simultaneous } \\
\text { model class selection and parametric identification, Computer- } \\
\text { Aided Civil and Infrastructure Engineering } \\
\text { Yuen, Mu (2015) }\end{array}$ & 2015 & 8.6338 & 2016 & 2019 & 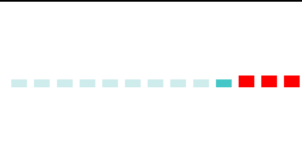 \\
\hline
\end{tabular}

Table 4. The top 12 strongest cited authors in the CACAIE from 2000 to 2019

\begin{tabular}{|c|c|c|c|c|c|}
\hline Rank & Cited authors & Strength & Begin & End & 2000-2019 \\
\hline 1 & Y.-J. Cha & 23.1668 & 2016 & 2019 & 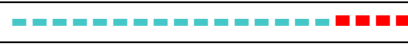 \\
\hline 2 & J. P. Amézquita-Sánchez & 15.8754 & 2016 & 2019 & 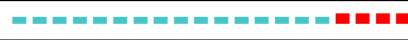 \\
\hline 3 & G. C. Marano & 14.1132 & 2012 & 2015 & 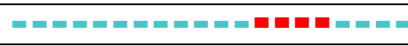 \\
\hline 4 & D. Goldberg & 12.8295 & 2000 & 2007 & 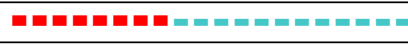 \\
\hline 5 & E. Castillo & 11.6001 & 2016 & 2019 & 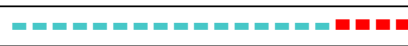 \\
\hline 6 & R. Jafarkhani & 10.9461 & 2012 & 2015 & 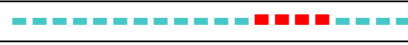 \\
\hline 7 & R. Putha & 10.5514 & 2012 & 2015 & 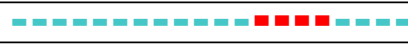 \\
\hline 8 & K. V. Yuen & 10.1528 & 2014 & 2019 & 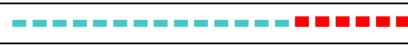 \\
\hline 9 & E. I. Vlahogianni & 9.7786 & 2008 & 2011 & 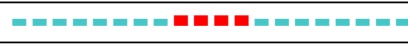 \\
\hline 10 & A. Stathopoulos & 9.4965 & 2007 & 2011 & 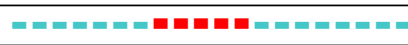 \\
\hline 11 & Y. Lecun & 9.4069 & 2017 & 2019 & 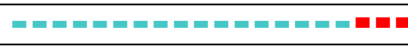 \\
\hline 12 & H. Sohn & 9.1201 & 2005 & 2011 & 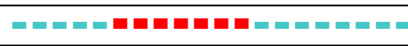 \\
\hline
\end{tabular}


Table 5. The top 10 strongest cited sources (journals) in the CACAIE from 2000 to 2019

\begin{tabular}{|c|c|c|c|c|c|}
\hline Rank & Cited sources (journals) & Strength & Begin & End & $2000-2019$ \\
\hline 1 & Structural Design of Tall and Special Buildings & 15.2537 & 2017 & 2019 & 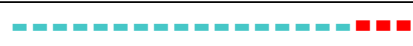 \\
\hline 2 & IEEE Conference on Computer Vision and Pattern Recognition & 12.6888 & 2016 & 2019 & 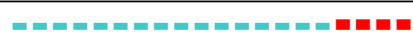 \\
\hline 3 & Nature & 12.3238 & 2016 & 2019 & 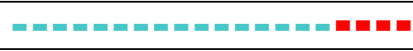 \\
\hline 4 & Microcomputers in Civil Engineering & 11.4798 & 2000 & 2006 & 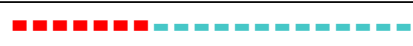 \\
\hline 5 & $\begin{array}{l}\text { Intelligent Infrastructure: Neural Networks, Wavelets, and } \\
\text { Chaos Theory for Intelligent Transportation Systems and } \\
\text { Smart Structures }\end{array}$ & 11.155 & 2013 & 2017 & 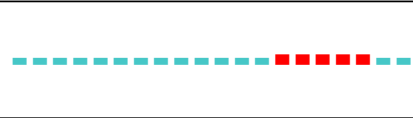 \\
\hline 6 & International Journal of Neural Systems & 10.8832 & 2009 & 2015 & 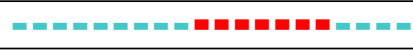 \\
\hline 7 & Archives of Computational Methods in Engineering & 10.5011 & 2016 & 2019 & 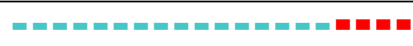 \\
\hline 8 & IEEE Transactions on Intelligent Transportation Systems & 9.8174 & 2017 & 2019 & 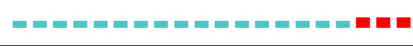 \\
\hline 9 & Genetic Algorithms in Engineering Systems & 9.4449 & 2000 & 2007 & 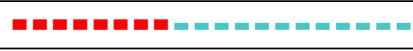 \\
\hline 10 & Engineering Optimization & 9.1694 & 2010 & 2015 & 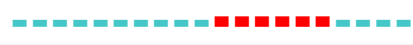 \\
\hline
\end{tabular}

\subsection{The most influential countries/regions and references}

Up to 31 December 2019, 1045 publications in CACAIE have been from 51 countries/regions since 2000. Figure 5 shows the distribution and the density around the world.

In Figure $5 \mathrm{a}, 51$ countries/regions cover five continents, mainly distributed in Australia, North America and Europe, and a few countries/regions are located in Asia, Africa and South America. In Figure 5b, the redder the colour is, the more publications the country/region has. The US and China are prominent to have more publications in CACAIE. In order to show the relationship and citation of countries/regions published in the journal clearly, citation analysis is made by VOSviewer to represent the influential countries/regions, shown in Figure 6.

As a result, the US is the most influential country with 421 publications and 11727 citations, followed by China, Spain, Taiwan, South Korea and Canada. In Figure 6a, 51 countries/regions are divided into 11 clusters, and a colour represents a cluster. Specifically, 11 countries/regions (red nods) belong to Cluster 1, i.e., Austria, Belgium, Germany, Italy, Latvia, Lithuania, Luxembourg, Malaysia, Taiwan, Vietnam, Yugoslavia. 8 countries/regions (blue nodes) belong to Cluster 2, i.e., Chile, Egypt, England, Mexico, New Zealand, Qatar, Scotland, Thailand. Cluster 3 contains 8 countries/regions (green nods), i.e., Australia, Denmark, Israel, Netherlands, South Africa, Spain, Sweden, Switzerland. Cluster 4 contains 7 countries/regions (yellow nods), i.e., Algeria, Canada, Colombia, Japan, Portugal, Saudi Arabia, South Korea. Cluster 5 consists of 6 countries/regions (purple nods), i.e., Greece, India, Serbia, Singapore, United Arab Emirates, US. 3 countries/regions (Finland, China, Poland) belong to Cluster 6 (orange nodes), and Cluster 7 contains also 3 countries/regions (brown nodes), i.e., Czech Republic, Iran, Turkey. France and Ireland belong to Cluster 8 . The last three clusters are Pakistan, Oman, and Wales, respectively, indicating that they have less relationship with other countries/regions. In Figure 6b, US, China and Canada have been cited earlier since 2006, and have bigger influence. Most of countries/ regions have been developed from 2010, such as Spain,
England and Germany. In addition, publications in some countries/regions (like South Africa, Malaysia and Pakistan) have been cited in recent years.

As for publications in CACAIE from 2000 to 2019, we make citation analysis by VOSviewer to present the influential publications. Let the minimum NC of a publication be 1,960 publications meet the threshold among 1045 publications. Figure 7 presents the citation analysis of publications in CACAIE.

The results show that the most influential publication is Cha et al. (2017), followed by Adeli (2001), Park et al. (2007), Opricovic, Tzeng (2002) and Kijewski, Kareem (2003). Tables 6 and 7 list detailed information of the top 10 most cited publications, and the top 10 most cited per year publications in the journal, respectively. As we can see, four same publications are both in Tables 6 and 7, and the publication "Deep learning-based crack damage detection using convolutional neural networks" written and published by Cha et al. (2017), has both the most citations (441) and AC (110.25).

In Table 6,9 of the top 10 most cited publications are Articles with at least two authors, and the other one is review, written by $\mathrm{H}$. Adeli. Except for domestic cooperation, 6 of these publications are international cooperation. It shows that cooperation is an effective way to produce high quality achievements in scientific research. The contents of them are mainly about crack damage detection, health monitoring of structures, sustainable reconstruction and system identification by some effective and popular methods, such as neural networks, wavelet transforms, and deep learning networks. In addition, 3 of them are about deep learning, published from 2017 or 2018, and they are also listed in Table 7, indicating that deep learning has been a hot topic in recent years, and has been paid attention to the scholars and journals.

In Table 7, all publications are done by at least two authors, and 9 publications are in collaboration with other institution(s), and half of them cooperate with another country. According to characteristics above, effective cooperation can give play to each author's advantages, and creative novel methods to deal with practical problems. 

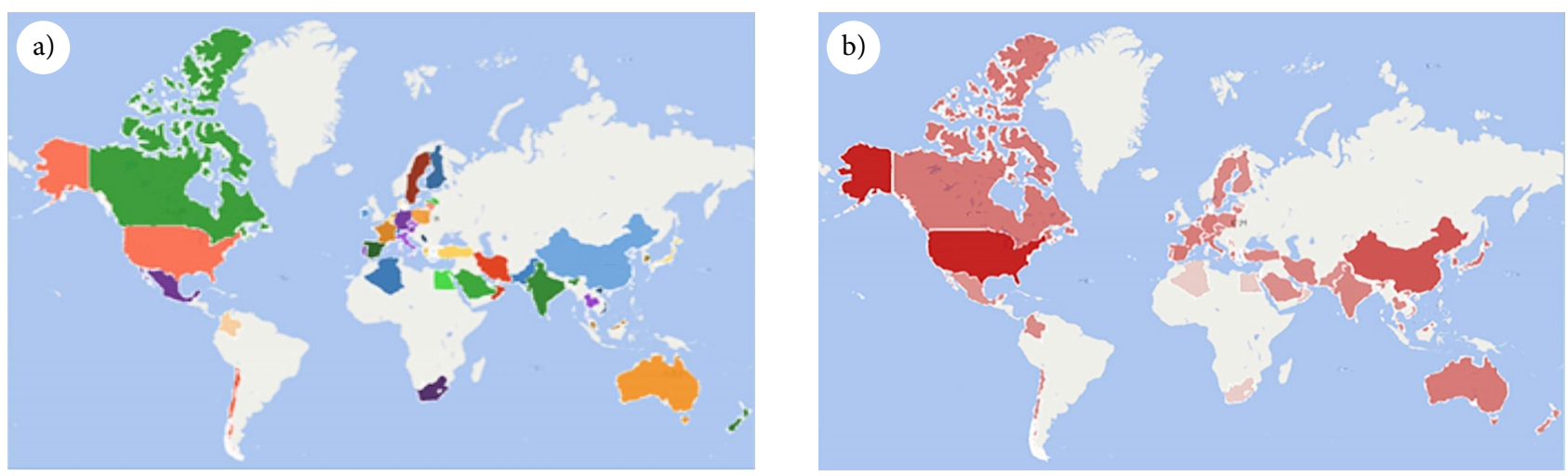

Figure 5. The distribution (a) and the density (b) of countries/regions published documents in the CACAIE
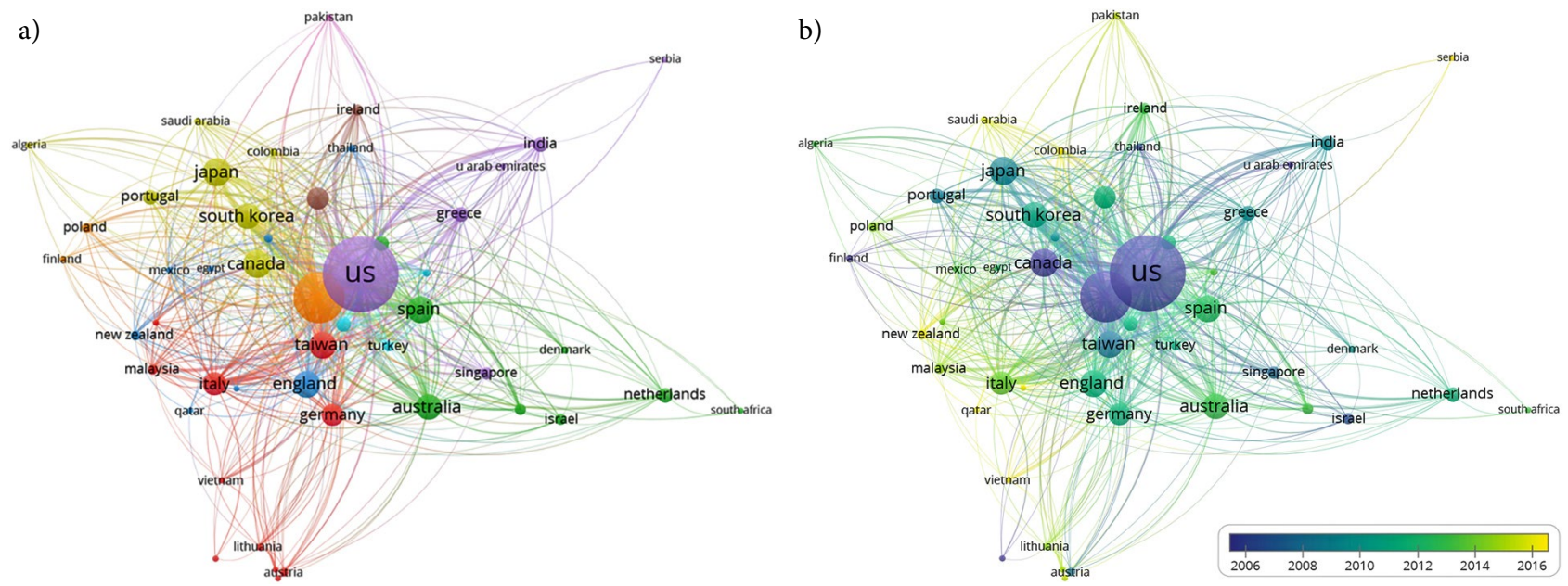

Figure 6. The citation analysis of countries/regions published documents in the CACAIE: $\mathrm{a}$ - the citation network; $\mathrm{b}$ - the time overlay network

a)

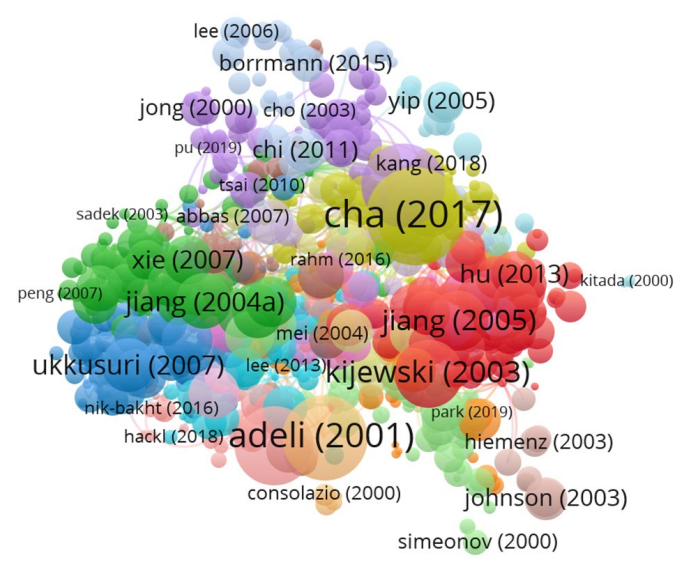

castillo (2000a) b)

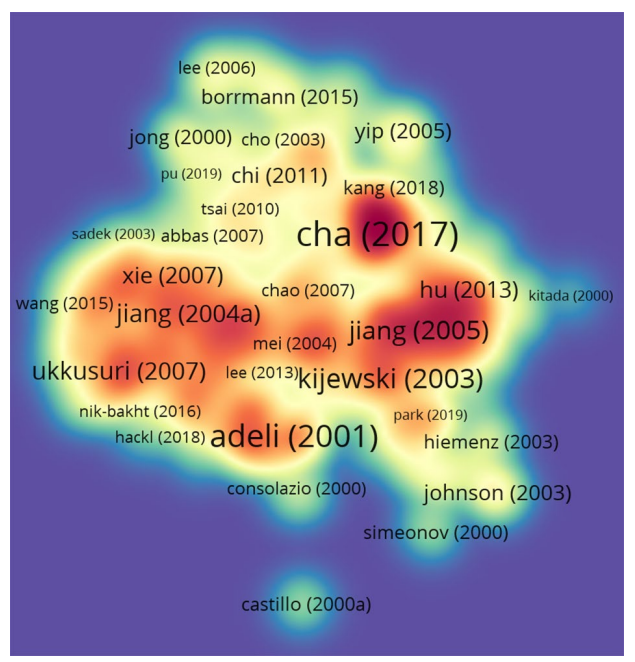

Figure 7. The citation analysis of publications in the CACAIE: a - the citation network of publications; $\mathrm{b}$ - the density visualization of publications

Considering year and contents, 8 of the top 10 AC publications are from 2017 or 2018, indicating that they have been concerned and cited many times since published. More than half publications are about deep learning or neural networks applied in civil engineering fields, espe- cially for crack damage detection and autonomous structural visual inspection. Obviously, deep learning and damage detection have been the most popular method and focused application in CACAIE in recent years. 
Table 6. The top 10 most cited publications from the CACAIE

\begin{tabular}{|c|c|c|c|c|c|c|c|c|c|}
\hline Rank & Title, author(s) & Type & Year & $\begin{array}{c}\text { No of } \\
\text { citations }\end{array}$ & $\mathrm{AC}$ & Author(s) & AN & IN & $\mathrm{CN}$ \\
\hline 1 & $\begin{array}{l}\text { Deep learning-based crack damage detection using } \\
\text { convolutional neural networks (Cha et al. 2017) }\end{array}$ & article & 2017 & 441 & 110.25 & $\begin{array}{l}\text { Y.-J. Cha, W. Choi, } \\
\text { O. Büyüköztürk }\end{array}$ & 3 & 2 & 2 \\
\hline 2 & $\begin{array}{l}\text { Neural networks in civil engineering: 1989-2000 } \\
\text { (Adeli 2001) }\end{array}$ & review & 2001 & 330 & 16.5 & H. Adeli & 1 & 1 & 1 \\
\hline 3 & $\begin{array}{l}\text { A new approach for health monitoring of } \\
\text { structures: terrestrial laser scanning (Park et al. } \\
\text { 2007) }\end{array}$ & article & 2007 & 318 & 22.71 & $\begin{array}{l}\text { H. S. Park, H. M. Lee, } \\
\text { H. Adeli, I. Lee }\end{array}$ & 4 & 3 & 2 \\
\hline 4 & $\begin{array}{l}\text { Multicriteria planning of post-earthquake } \\
\text { sustainable reconstruction (Opricovic, Tzeng 2002) }\end{array}$ & article & 2002 & 285 & 15 & S. Opricovic, G.-H. Tzeng & 2 & 2 & 2 \\
\hline 5 & $\begin{array}{l}\text { Wavelet transforms for system identification in } \\
\text { civil engineering (Kijewski, Kareem 2003) }\end{array}$ & article & 2003 & 211 & 11.72 & T. Kijewski, A. Kareem & 2 & 1 & 1 \\
\hline 6 & $\begin{array}{l}\text { Dynamic wavelet neural network for nonlinear } \\
\text { identification of highrise buildings (Jiang, Adeli } \\
\text { 2005a) }\end{array}$ & article & 2005 & 167 & 10.44 & X. Jiang, H. Adeli & 2 & 1 & 1 \\
\hline 7 & $\begin{array}{l}\text { Autonomous structural visual inspection using } \\
\text { region-based deep learning for detecting multiple } \\
\text { damage types (Cha et al. 2018) }\end{array}$ & article & 2018 & 155 & 51.67 & $\begin{array}{l}\text { Y.-J. Cha, W. Choi, G. Suh, } \\
\text { S. Mahmoudkhani, } \\
\text { O. Büyüköztürk }\end{array}$ & 5 & 2 & 2 \\
\hline 8 & $\begin{array}{l}\text { Automated pixel-level pavement crack detection } \\
\text { on 3D asphalt surfaces using a deep-learning } \\
\text { network (Zhang et al. 2017) }\end{array}$ & article & 2017 & 147 & 36.75 & $\begin{array}{l}\text { A. Zhang, K. C. P. Wang, } \\
\text { B. Li, E. Yang, X. Dai, Y. } \\
\text { Peng, Y. Fei, Y. Liu, J. Q. } \\
\text { Li, C. Chen } \\
\end{array}$ & 10 & 2 & 2 \\
\hline 9 & $\begin{array}{l}\text { Wavelet packet-autocorrelation function method } \\
\text { for traffic flow pattern analysis (Jiang, Adeli 2004) }\end{array}$ & article & 2004 & 138 & 8.12 & X. Jiang, H. Adeli, & 2 & 1 & 1 \\
\hline 10 & $\begin{array}{l}\text { Robust transportation network design under } \\
\text { demand uncertainty (Ukkusuri et al. 2007) }\end{array}$ & article & 2007 & 128 & 9.14 & $\begin{array}{l}\text { S. V. Ukkusuri, } \\
\text { T. V. Mathew, S. T. Waller }\end{array}$ & 3 & 3 & 2 \\
\hline
\end{tabular}

Notes: AC - average citations per publication; AN - the number of authors; IN - the number of institutions; CN - the number of countries/regions.

Table 7. The top 10 most cited per year publications from the CACAIE

\begin{tabular}{|c|c|c|c|c|c|c|c|c|c|}
\hline Rank & Title, author(s) & Type & Year & $\begin{array}{c}\text { No of } \\
\text { citations }\end{array}$ & $\mathrm{AC}$ & Author(s) & $\mathrm{AN}$ & IN & $\mathrm{CN}$ \\
\hline 1 & $\begin{array}{l}\text { Deep learning-based crack damage detection using } \\
\text { convolutional neural networks (Cha et al. 2017) }\end{array}$ & article & 2017 & 441 & 110.25 & $\begin{array}{l}\text { Y.-J. Cha, W. Choi, } \\
\text { O. Büyüköztürk }\end{array}$ & 3 & 2 & 2 \\
\hline 2 & $\begin{array}{l}\text { Autonomous structural visual inspection using } \\
\text { region-based deep learning for detecting multiple } \\
\text { damage types (Cha et al. 2018) }\end{array}$ & article & 2018 & 155 & 51.67 & $\begin{array}{l}\text { Y.-J. Cha, W. Choi, G. Suh, } \\
\text { S. Mahmoudkhani, } \\
\text { O. Büyüköztürk }\end{array}$ & 5 & 2 & 2 \\
\hline 3 & $\begin{array}{l}\text { Automated pixel-level pavement crack detection on } \\
\text { 3D asphalt surfaces using a deep-learning network } \\
\text { (Zhang et al. 2017) }\end{array}$ & article & 2017 & 147 & 36.75 & $\begin{array}{l}\text { A. Zhang, K. C. P. Wang, } \\
\text { B. Li, E. Yang, X. Dai, Y. } \\
\text { Peng, Y. Fei, Y. Liu, J. Q. Li, } \\
\text { C. Chen }\end{array}$ & 10 & 2 & 2 \\
\hline 4 & $\begin{array}{l}\text { Structural damage detection with automatic } \\
\text { feature-extraction through deep learning (Lin et al. } \\
\text { 2017) }\end{array}$ & article & 2017 & 126 & 31.5 & $\begin{array}{l}\text { Y.-Z. Lin, Z.-H. Nie, } \\
\text { H.-W. Ma }\end{array}$ & 3 & 4 & 1 \\
\hline 5 & $\begin{array}{l}\text { Deep transfer learning for image-based structural } \\
\text { damage recognition (Gao, Mosalam 2018) }\end{array}$ & article & 2018 & 73 & 24.33 & Y. Gao, K. M. Mosalam & 2 & 3 & 2 \\
\hline 6 & $\begin{array}{l}\text { Short-term traffic speed prediction for an urban } \\
\text { corridor (Yao et al. 2017) }\end{array}$ & article & 2017 & 91 & 22.75 & $\begin{array}{l}\text { B. Yao, C. Chen, Q. Cao, } \\
\text { L. Jin, M. Zhang, H. Zhu, } \\
\text { B. Yu }\end{array}$ & 7 & 3 & 1 \\
\hline 7 & $\begin{array}{l}\text { A new approach for health monitoring of } \\
\text { structures: terrestrial laser scanning (Park et al. } \\
2007 \text { ) }\end{array}$ & article & 2007 & 318 & 22.71 & $\begin{array}{l}\text { H. S. Park, H. M. Lee, } \\
\text { H. Adeli, I. Lee }\end{array}$ & 4 & 3 & 2 \\
\hline 8 & $\begin{array}{l}\text { A fast detection method via region-based fully } \\
\text { convolutional neural networks for shield tunnel } \\
\text { lining defects (Xue, Li 2018) }\end{array}$ & article & 2018 & 67 & 22.33 & Y. Xue, Y. Li & 2 & 1 & 1 \\
\hline 9 & $\begin{array}{l}\text { Vision-based automated crack detection for bridge } \\
\text { inspection (Yeum, Dyke 2015) }\end{array}$ & article & 2015 & 127 & 21.17 & C. M. Yeum, S. J. Dyke & 2 & 2 & 1 \\
\hline 10 & $\begin{array}{l}\text { Automatic pixel-level crack detection and } \\
\text { measurement using fully convolutional network } \\
\text { (Yang et al. 2018) }\end{array}$ & article & 2018 & 60 & 20 & $\begin{array}{l}\text { X. C. Yang, H. Li, Y. Yu, } \\
\text { X. Luo, T. Huang, X. Yang }\end{array}$ & 6 & 2 & 1 \\
\hline
\end{tabular}

Notes: AC - average citations per publication; AN - the number of authors; IN - the number of institutions; CN - the number of countries/regions. 


\subsection{Collaboration network at level of country/region, institution and author}

The collaboration networks can reflect cooperative relations of publications between the connected countries/ regions, institutions and authors. To do so, we make coauthorship analysis of publications in the journal from 2000 to 2019. By means of VOSviewer, let the minimum NP of a country/region be 5, 30 countries/regions meet the threshold among 51 countries/regions. Figure 8 shows the collaboration network at level of country/region after association strength, that is one of the normalization methods.

A node represents a country/region, and a link connected two countries/regions means their compactness degree of relationship. The bigger the node is, the more NP the country/region has. Similarly, the thicker the link is, the closer the two countries/regions are. The total link strength with other countries/regions is calculated for each of the 30 countries/regions. The leading country is US with total link strength is 178 , followed by China, Japan, Australia and England. In Figure 8, 30 countries/regions have 112 links and 328 total link strength, classified into 9 clusters, and each colour represents a cluster. Specifically, France, Germany, India, Ireland, Singapore belong to Cluster 1; England, Italy, Malaysia, Scotland, Switzerland belong to Cluster 2; Cluster 3 contains Austria, Greece, Lithuania, China; Cluster 4 contains Australia, Canada, Netherlands, Sweden; Cluster 5 consist of Colombia, Portugal, Spain; Cluster 6 consist of Taiwan, Turkey, US; Israel, South Korea belong to Cluster 7; Cluster 8 contains Japan, Poland; Cluster 9 has Iran and New Zealand.

Similarly, Figure 9 shows the collaboration network at level of institution. Let the minimum NP of an institution be 10, 30 institutions meet the threshold among 738 institutions. Caltech (US) ranks the first with 18 publications and 472 citations, and total link strength is 13 , followed by University of Illinois Urbana-Champaign (US), Hong Kong University of Science and Technology (China), Tongji University (China) and Harbin Institute of Technology (China). In Figure 9, there are 46 links and 65 total link strength. Most of influential institutions are from US and China, and 30 institutions are classified into 7 clusters. Specifically, Cluster 1 contains Delft University of Technology (Netherlands), Indian Institute of Technology Delhi (India), Purdue University (US), Ryerson University (Canada), Texas A\&M University (US), University of Texas at Austin (US), University of Waterloo (Canada); Cluster 2 consists of California Institute of Technology (US), Dalian University of Technology (China), Harbin Institute of Technology (China), Hong Kong Polytechnic University (China), Dresden University of Technology (Germany); Cluster 3 has Georgia Institute of Technology (US), Ohio State University (US), Technion - Israel Institute of Technology (Israel), University of California, Berkeley (US), Yonsei University (Korea); Cluster 4 contains Hong Kong University of Science and Technology (China), Tongji University (China), University of Cantabria (Spain), University of Macau (China); Cluster 5 consists of Ibaraki University (Japan), Southeast

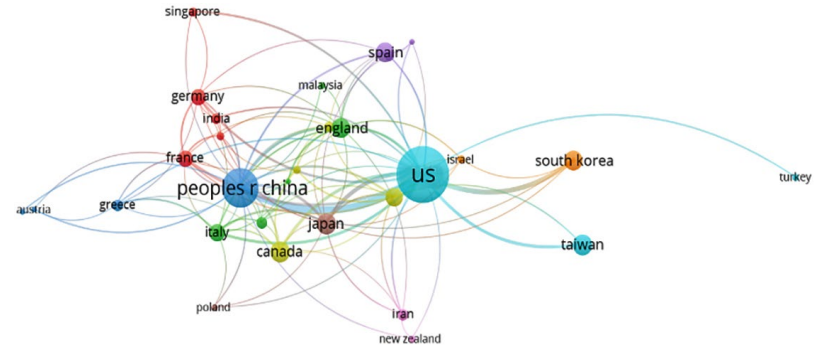

Figure 8. The collaboration network at level of country/region

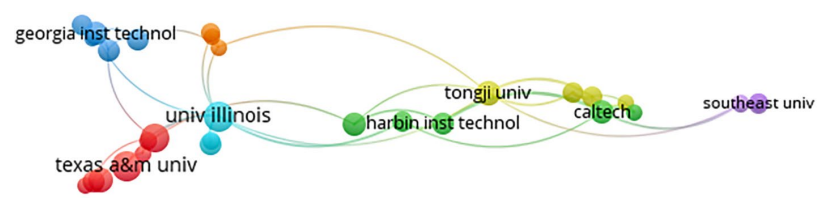

Figure 9. The collaboration network at level of institution

University (China), University of California, Irvine (US); Cluster 6 has Tsinghua University (China), University of Illinois Urbana-Champaign (US), University of Maryland (US); Finally, National Chiao Tung University (Taiwan, part of China), National Taiwan University (Taiwan, part of China), University of Wisconsin (US) belong to Cluster 7.

In the following, we make co-authorship analysis of authors. Let the minimum NP of an author be 2, 368 authors meet the threshold among 2481 authors. Figure 10 shows the collaboration network at level of author. Due to that many of the 368 authors are not connected to each other, they are represented as independent nodes, shown in Figure 10a, and 368 authors have 420 links and 763 total link strength, classified into 134 clusters. The largest set of connected authors consists of 33 authors, and we zoom in to see clearly, shown in Figure 10b. As for the total link strength, E. Castillo is the leading author with 34 link strength, followed by S. T. Waller, Z. Grande, J. I. Beck, and K. C. P. Wang. It indicates that E. Castillo performs well in cooperation. In terms of citation, H. Adeli has the most citations although the total link strength is 8 , indicating that he is good at writing great publications by himself.

\subsection{Co-occurrence and timeline view of keywords}

Keywords are effective and important information to show the research topics of publications in CACAIE. Co-occurrence analysis is a way to provide a view of the knowledge structure by text mining, and timeline view elaborates the research trend during a certain time. In the following, cooccurrence analysis of publications in CACAIE from 2000 to 2019 is made by VOSviewer. Let the minimum number of occurrences of a keyword be 10, and 77 keywords meet the threshold among totally 1483 keywords. Figure 11 shows the keyword co-occurrence network of publications in CACAIE. "Model" occurs 197 times, and has the most total link strength, followed by "optimization", "system", "design" and "algorithm", indicating that publications in the journal place emphasis on these keywords. 
a)

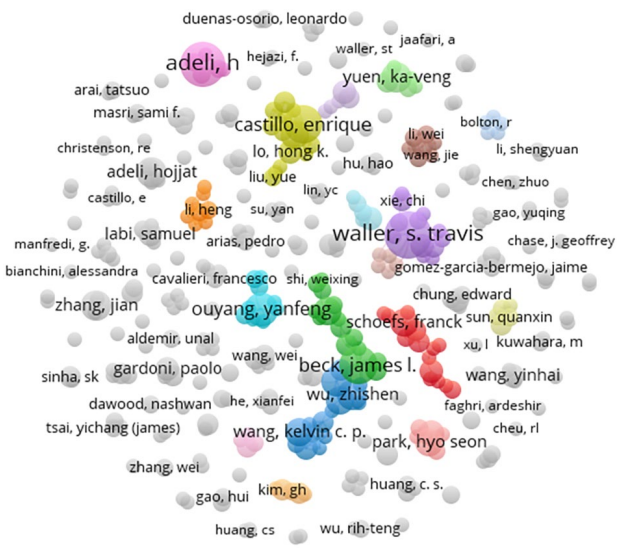

b)

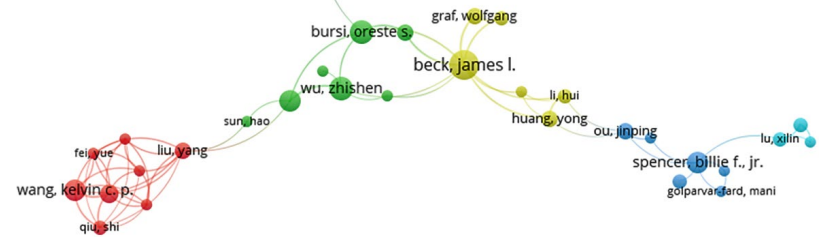

Figure 10. The collaboration network at level of author: a - the network with 368 authors;

$\mathrm{b}$ - the largest connected network with 33 authors

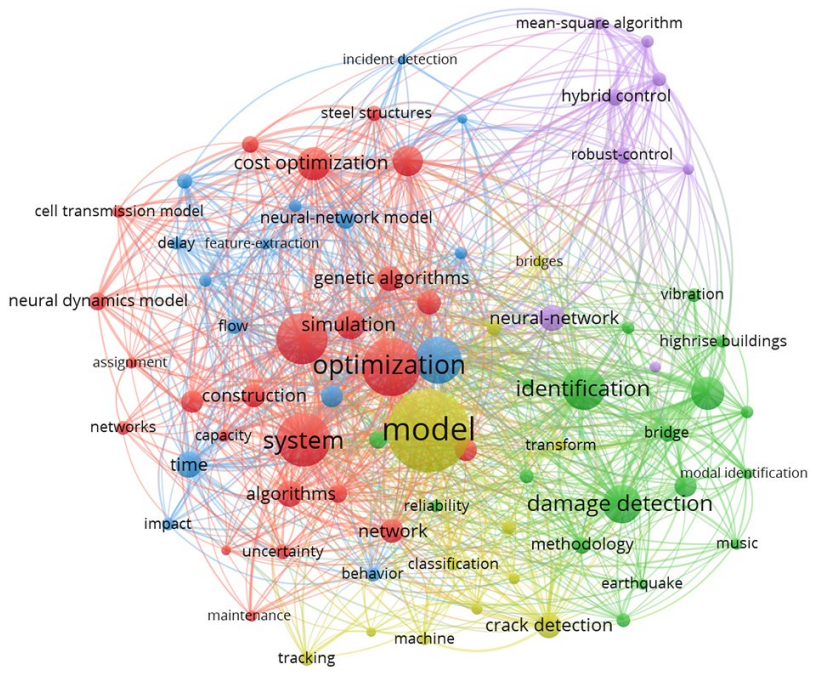

Figure 11. The keyword co-occurrence network of publications in the CACAIE

In Figure 11, all keywords are divided into 5 clusters. In general, "genetic algorithms", "cost optimization", and "construction", etc., are included in red cluster. Green cluster has "damage detection", "methodology" and "earthquake", etc. "Classification", "machine" and "crack detection" are prominent in yellow cluster. "Neural-network model", "incident detection" and "feature-extraction", etc., are labelled in blue cluster. "Hybrid control", "mean-square algorithm", and "robust-control", etc., are highlighted in purple cluster.
In order to represent the keywords of publications in CACAIE from 2000 to 2019, all keywords are integrated over time by CiteSpace. Let time slice be 4 , and the trend of keywords is depicted, shown in Figure 12. Keywords are mainly divided to 8 categories from time's perspective. To be specific, "wavelet neural network" is the largest class, ranged from 2000 to 2018, and the contains includes "damage detection", "neural network", "system identification" and "network design". The second is "construction" from 2000 to 2016, and it focuses more on "reliable assessment", "concrete", "formulation framework" and "vulnerability earthquake". The third class is "capacity", where publications are around from 2005 to 2018, and keywords of "propagation", "selection" and "deep inspection" occur frequently. "Cost optimization" is the fourth class from 2000 to 2016, and it pays more attention to "structural optimization", "frame roof structure", and " 2 phase genetic algorithm". The fifth class is "incident detection" from around 2002 to 2013, and the publications prefer to occur keywords like "feature extraction", "volume zone capacity" and "delay". Next, "parallel algorithm" is the sixth class, emphasized on "flow", "square algorithm", and "active control". The following class is "algorithm", focused on "repair policy", "estimation model" and "algorithm load". Finally, "user equilibrium" is the last class, and it has been developed in recent years. Over time, the topic and popular keywords of publications in CACAIE have changed continually, and the journal has paid more attention to machine learning algorithms and network structure designing in the fields of construction and building technology, civil engineering, transportation science and technology, and computer science with advanced methods in the age of big data.

\section{Research in relevant fields}

According to bibliometric analysis of publications in CACAIE from 2000 to 2019, general characteristics are revealed and studied. The journal always focuses on recent advances in computer and information technologies and fosters the development and application of new and emerging computing paradigms and technologies. In this section, the researches are explored after summarizing relevant publications on the fields of the journal, i.e., construction and building technology (Zagorskas, Turskis 2020), civil engineering (Kuzhel et al. 2013), transportation science and technology (Mardani et al. 2016), computer science (Sokolovskij 2007; Prentkovskis et al. 2010).

\subsection{At Construction \& Building Technology level}

In WoS, there are 63 journals in the field of Construction \& Building Technology, and CACAIE ranks the first, indicating that publications in the journal make a great contribution and have been recognized by scholars in this field. We review and summarize relevant publications in the journal, and the contents refer to three aspects, shown in Figure 13: 


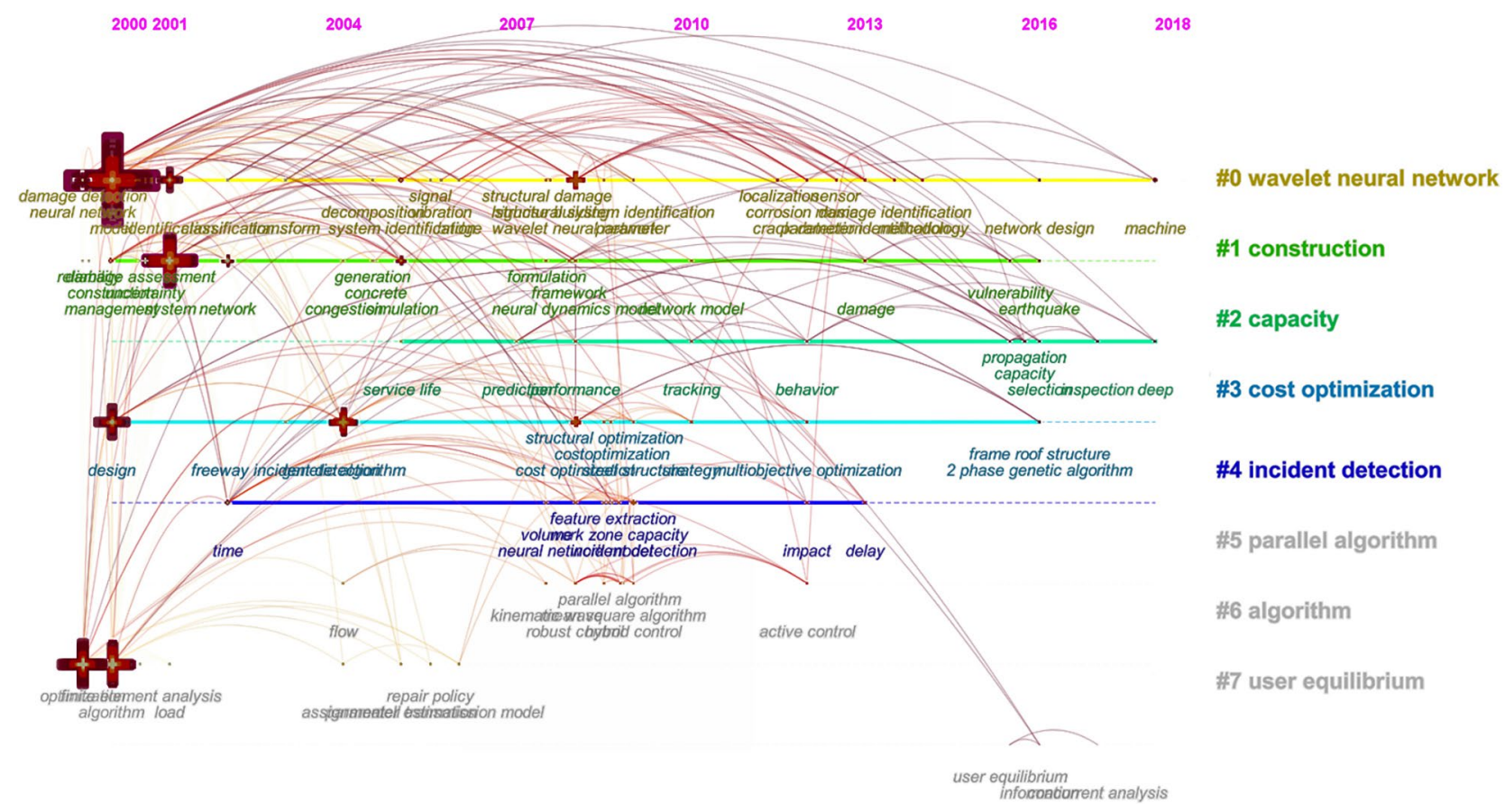

Figure 12. The timeline view of keywords in the CACAIE

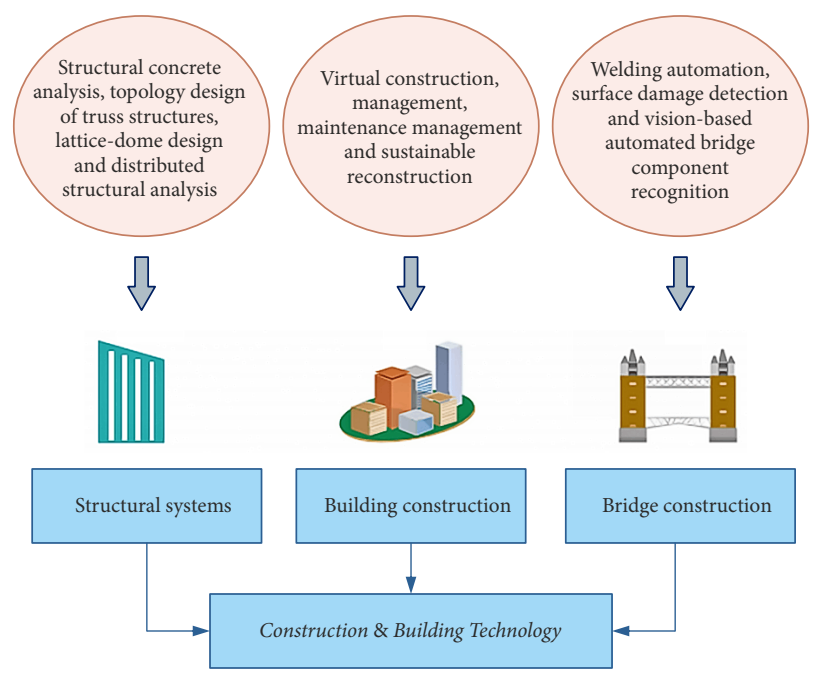

Figure 13. Research topics of Construction \& Building Technology

- Structural systems. Structural concrete analysis, topology design of truss structures, lattice-dome design and distributed structural analysis are common research objects in structural systems. A series of methods have been proposed, such as nonlinear analysis with state-space approach, rigid-body-spring networks, knowledge-based system approach and artificial neural networks. Moreover, structural systems contain structural steel design, structural monitoring system, structural parameter estimation and smart construction. For example, web-based interactive courseware with Java, parallel processing and vectorization and bi-level parallel genetic algorithms have been studied for structural steel design. Health moni- toring and structural reliability have been researched as a value chain by sensitivity analysis, neural network and probabilistic measures;

- Building construction. It is the process of preparing for and forming buildings and building systems. Construction starts with planning, design, and financing and continues until the structure is ready for occupancy. Virtual construction, construction management, maintenance management and sustainable reconstruction are key research directions in building construction. For example, industry foundation classes-based graphic information models have been developed and implemented. Multi-objective and stochastic systems have been established for building maintenance management. Moreover, scholars have given frameworks for city-scale building seismic resilience simulation and repair scheduling with labour constraints driven by time-history analysis;

- Bridge construction. There are kinds of types for bridge around the world, such as long-span suspension bridges, scissor-type bridges, mobile bridges and railway bridges. Different bridges have their features, and there have been 70 publications about bridge construction. Up to now, scholars have studied welding automation, surface damage detection and vision-based automated bridge component recognition for various bridge construction.

\subsection{At Engineering, Civil level}

CACAIE is a leading journal in the field of Engineering, Civil among 134 journals with the same research direction. Civil engineering is a professional engineering discipline that deals with the design, construction, and maintenance 
of the physical and naturally built environment, including works like roads, bridges, canals, dams, and buildings. The aim of CACAIE mainly considers infrastructure systems, water resources engineering, geotechnical engineering and environmental issues, shown in Figure 14:

- Infrastructure systems. It is one of the key parts in civil engineering, and refers to multiple aspects, such as maintenance, assessment and repairmen. Scholars need to make integrate inspection scheduling and maintenance planning, and discuss the vulnerability of interdependent infrastructure networks. On the other hand, multi-attribute selection has also been considered from alternative designs of infrastructure components, and some mathematical frameworks have been proposed for quantifying and optimizing protective actions. In terms of post disaster infrastructure systems, scholars have studied how to improve repair sequence scheduling, and determine an optimal maintenance period. In addition, infrastructure systems contain highways, bridges, pavements, airports and utilities, that all are research objects. For example, asphalt pavement repair system has been modelled considering fuzziness of budget constraints; Three-dimensional optimization have been designed for hydropower forecasting system and urban drainage systems;

- Water resources engineering. Water distribution systems are researched most related to computer-aided design, steady-state analysis and optimal recovery from disruptions. For example, serviceability assessment of municipal water systems has been proposed under spatially correlated seismic intensities; Evolutionary optimization techniques have been used for scheduling water pipe renewal considering a short planning horizon. In terms of water flow, pore pressure and viscous shear stress distribution have been analysed due to water flow within asphalt pore structure. Identification and adaptive control have been studied for open channel water flow systems;

- Geotechnical engineering. It is an important branch of civil engineering concerned with the engineering

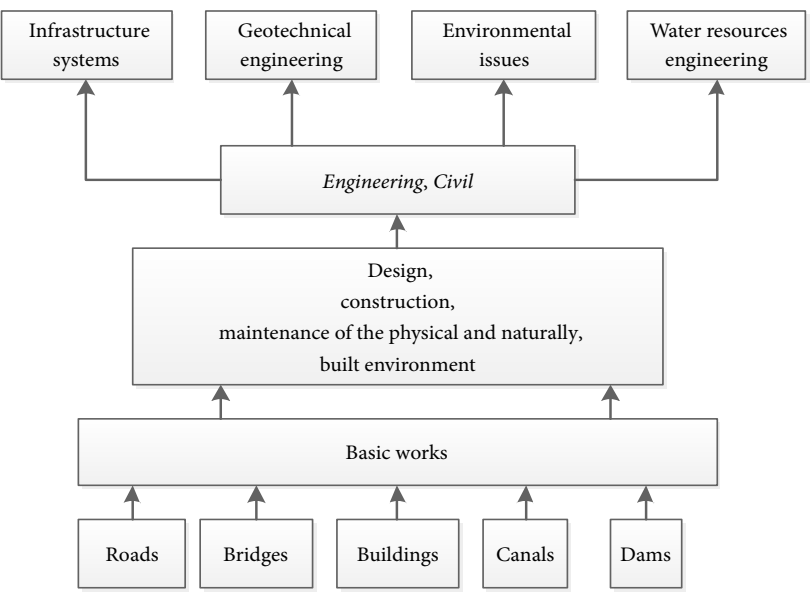

Figure 14. Publications in the field of Engineering, Civil behaviour of earth materials, and has applications in military, mining, petroleum and other engineering disciplines that are concerned with construction occurring on the surface or within the ground. As for geotechnical engineering of dam foundation, 3D parametric modelling of complex geological structures has been established based on T-splines. Scholars have predicted geotechnical parameters of sands from cone penetrometer test measurements using advanced technologies, such as neural networks. Moreover, reinforced concrete belongs to geotechnical engineering, and it has been studied for diagnosing cracks, life-cycle performance analysis, impactresistant design and risk management;

- Environmental issues. Considering environmental and internal conditions, a serious of researches have been studied, like changes in modal properties of a concrete box-girder bridge. In addition, a rapidly convergent empirical mode decomposition method has been established for analysing the environmental temperature effects on stay cable force; Probabilistic baseline of finite element model of bridges has been proposed under environmental temperature changes; Variance-reduction and space-filling approaches have been compared for the design of environmental monitoring networks; Models have been analyzed from neural networks to qualitative models in environmental engineering.

\subsection{At Transportation Science \& Technology level}

There are totally 36 journals in the field of Transportation Science \& Technology, and CACAIE is a leading journal that ranks the first for many years. The publications in the journal have given valuable references for scholars, and they mainly reflect in transportation, highway and Geographic Information Systems (GIS), shown in Figure 15:

- Transportation. It is a wide research direction including traffic flow, traffic incident detection and traffic signal timing optimization. The journal has published about 113 documents referred to above directions. Specifically, scholars have used a serious of methods to simulate or optimize traffic flow, such as mode-split traffic-assignment method, time-series analysis and pulse-and-glide strategy. As for traffic incident detection, wavelet transform is the popular method to solve such problems, and related publications almost have been high-cited. For instance, feature extraction can be obtained by using wavelet transform and linear discriminant analysis, and relevant methods contain the adaptive conjugate gradient neural network-wavelet model and waveletclustering-neural network model. Another research topic is traffic signal timing optimization, and signal timing involves deciding how much green time the traffic lights shall provide at an intersection approach, how long the pedestrian walk signal should be, and many numerous other factors. So far, publications have studied some advanced algorithm, such as 


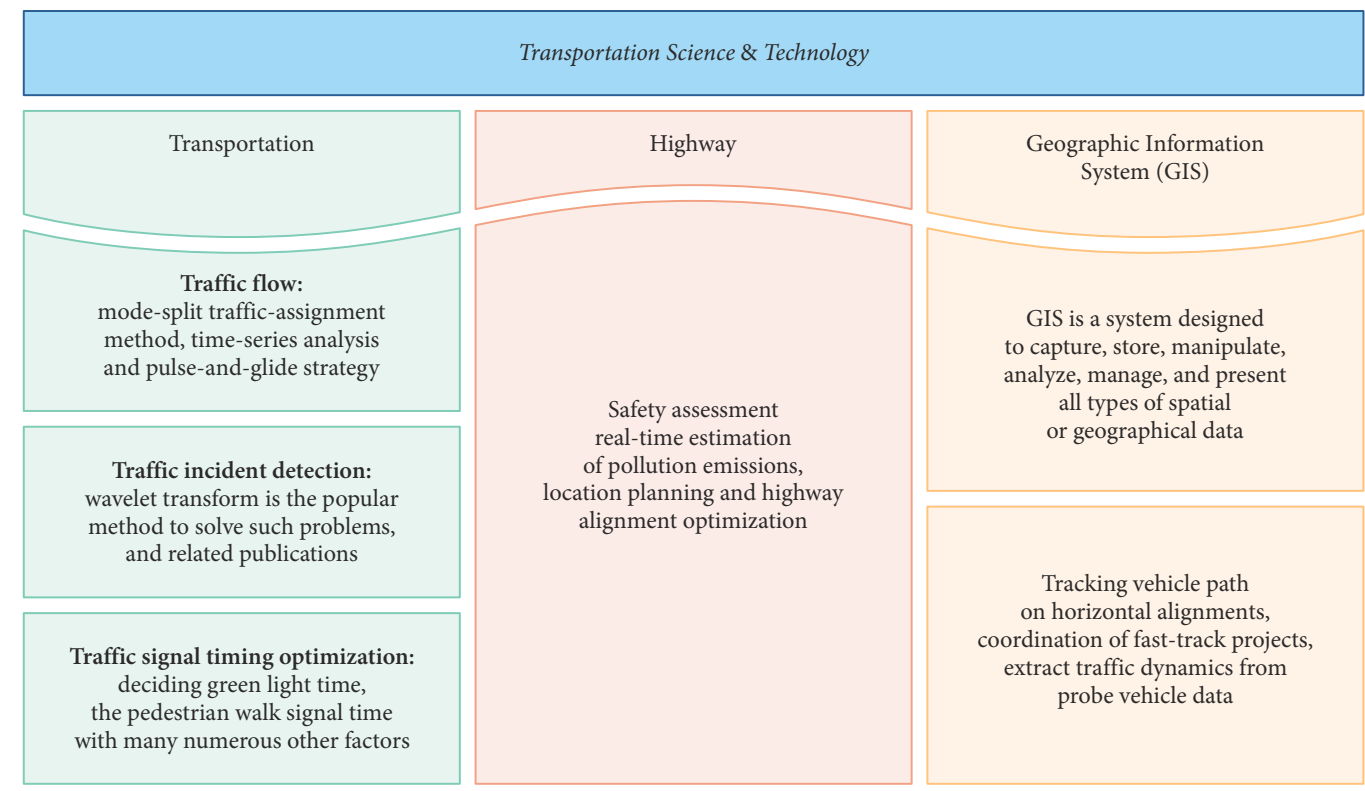

Figure 15. Publications in the field of Transportation Science \& Technology

artificial neural network-based heuristic, data-driven computational approach, bi-level programming formulation and heuristic solution approach;

- Highway. It is a common and necessary means of transportation in many countries. 71 publications have made research about it, which refer to safety assessment, real-time estimation of pollution emissions, location planning and highway alignment optimization. Different countries have their characteristics in highway construction considering terrain, economic development and government policy. For example, scholars in China have preferred to research alignment optimization because of vigorous construction and large flow of people, especially during holidays;

- GIS. It is a system designed to capture, store, manipulate, analyse, manage, and present all types of spatial or geographical data. With the help of GIS, researchers have studied for tracking vehicle path on horizontal alignments, coordination of fast-track projects and extract traffic dynamics from probe vehicle data. Moreover, all earth-based spatial-temporal location and extent references should be relatable to one another and ultimately to a "real" physical location or extent, and it is an important feature of GIS that has begun to open new avenues of scientific inquiry.

\subsection{At Computer Science, Interdisciplinary Applications level}

Computer Science, Interdisciplinary Applications is a big and popular research direction and has been applied in many fields. CACAIE ranks the 5th among 109 journals in Computer Science, Interdisciplinary Applications, staying ahead in the journals. At computer science level, publications in CACAIE from 2000 to 2019 can be boiled down to five aspects, shown in Figure 16:

- Artificial intelligence. In WoS, this first publication related to artificial intelligence established a hybrid artificial-intelligence-based system for site layout planning in construction in 2001. Later, artificial intelligence technologies have been applied to pavement management, decision support systems, and performance modelling. For example, computer vision techniques used for automatic structural assessment of underground pipes. Non-destructive evaluation of elastic properties of concrete was researched by using simulation of surface waves. Rapid humanassisted creation of bounding models was proposed for obstacle avoidance in construction. On the other hand, artificial intelligence contains multiple techniques, and we divide them into evolutionary algorithms, machine learning and virtual reality:

- Evolutionary algorithms. It is a very useful tool to optimize performance in suitable models, and scholars has applied them for damage detection to finite element model updating, for scheduling water pipe renewal considering a short planning horizon, for model-free identification of hysteretic systems, or for optimization of bridge deck repairs, etc. In publications, there are many evolutionary algorithms, such as genetic algorithm, swarm-gradient algorithm and meta-heuristic algorithm, etc. Especially, genetic algorithm has performed very prominent in these publications. For example, it has been used to optimize stopping patterns for passenger rail transportation, and pre-screen and repair for highway alignment optimization. A modified genetic algorithm was established for the dynamic identification of structural systems;

- Machine learning. With the advances in scientific algorithms, machine learning as an important tool has played a key role in publications applied for crack assessment of reinforced concrete shells, 
seismic vulnerability assessments and pavement crack detection. Neural network, encoder-decoder and support vector machine are several common machine learning algorithms used of publications in CACAIE. Among them, neural network is the most used algorithm, and there are more than 200 publications about it. Since 2016, deep learning algorithms have become popular to improve performance of models, and the related publications have made bigger influence, that scholars have preferred to learn from them and cite them;

- Virtual reality. Combined with simulation and visualization techniques, the topic has studied for riskfree transport studies by a cyber-physical system simulator, and for highway route planning using a tangible terrain representation system. This kind of techniques has realistic significance. For example, interactive real-time simulations and humanoid avatars on consumers' responses has been applied in online house products marketing. 3D reconstruction can deal with semi-automated detection of design errors, and lattice-Boltzmann methods help to simulate indoor flows;

- Software engineering. Parallel processing and distributed computing have used mostly in publications. Early stage, integration of general sparse matrix and parallel computing technologies have been used for large-scale structural analysis. Bi-level parallel genetic algorithms have been studied for optimization of large steel structures. Advanced analysis of steel frames has been made depending on parallel processing and vectorization. Later, distributed computing has been growing up gradually. Distributed simulation for freeway traffic flow has been applied for realtime estimation of time-variant parameters. Distributed algorithm has also used for retrofit design on a multi-core PC cluster;

- Robotics. It can be regarded as automated machines that can take the place of humans in dangerous environments or manufacturing processes, or resemble humans in appearance, behaviour, and cognition. In publications, classical planning model-based approach to automating construction planning has been proposed on earthwork projects. The method to balance human-and-robot integration has been established in building tasks. Deployable truss operation by ETS-VII robot arm has been structured using force accommodation control. Fully automated shotcrete robot has also been designed for rock support. Robotic research has made works safer and more effective in engineering;

- Decision support system. It is a computer-based information system that supports business or organizational decision-making activities. At present, various decision support systems combined with data management systems have been proposed for construction quality inspection, flexible pavement treatment selection, cost escalation in heavy engineering industry and waterproofing of below-grade structures. In addition, consistency evaluation is a branch of decision support system, and has also used widely, such as consistency-based problem solving for environmental decision support and consistency assessment of landscape design;

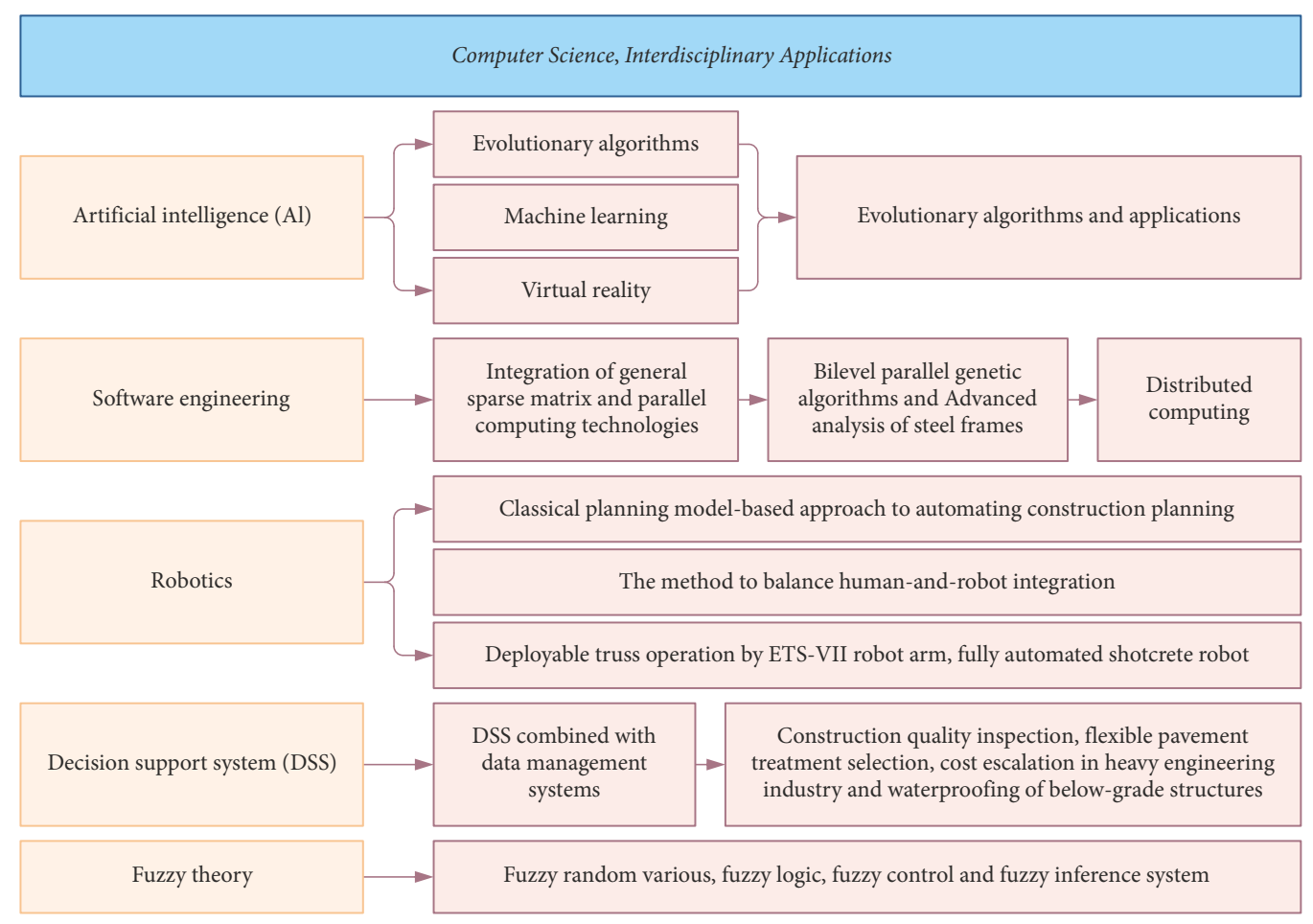

Figure 16. Publications related to Computer Science, Interdisciplinary Applications 
- Fuzzy theory. There are about 65 publications used fuzzy theory in CACAIE, and it mainly refers to fuzzy random various, fuzzy logic, fuzzy control and fuzzy inference system. For example, fuzzy Monte Carlo simulation has made risk assessment in construction; neuro-fuzzy reasoning has been proposed to predict pavement performance; fuzzy analytic hierarchy process synthetic evaluation models have been established for the health monitoring of shield tunnels. As we can see, it is a strong tool to help people make decisions, and optimize models' performances.

\section{Further discussions}

According to ranks and influence in the relevant fields, CACAIE has already been in the lead in journals. With the advent of technology and global economic changes, each journal has made the most of their advantages to improve the influence of the journal and attract scholars. Combined with characteristics and research of publications in CACAIE, three aspects are addressed for the journal and scholars for further discussions and investigations:

- so far, 51 countries/regions have publications in the journal, mainly distributed in Australia, North America and Europe, while there are more than 200 countries/regions in the world. The reason may be that the requirement of the journal is very high, and manuscripts need to have enough innovation that can be published so that it depends on academic level in each country/region. On the other hand, there exists some technological gap in countries/regions, such as construction and building, transportation science, and computer science. Therefore, scholars in various countries/regions can pay attention to this journal to know hot topics and influential authors/ institutions, and publish documents through international cooperation;

- according to high-cited publications and timeline view of keywords, researches based on deep learning algorithms have been obvious trends in various fields, because of higher effective and better performance. Until now, deep neural networks have been the most popular algorithms applied in crack damage detection, health monitoring of structures, and image-based structural damage recognition. As far as we are concerned, with the practical problem are more complex and abstract, multi-scale technologies may be a way to deal with them. For example, decision support system with deep learning algorithms are used for risk assessment and maintenance management. GIS with AI technologies can deal with massive data and obtain features quickly for extracting traffic dynamics and optimizing traffic flow;

- in terms of research content of publications in CACAIE, there are more theoretical researches than application researches, because it is the cornerstone of applied research after all. On the one hand, more novel frameworks or methods are encouraged to promote relevant industries progress. On the other hand, considering civil engineering, building and transportation research are widespread in real life, it is better to present more application cases based on theoretical knowledge, because it may provide more references for scholars to understand contributions and apply them in real-world issues.

In addition, there are other aspects, which can be discussed based on bibliometric analysis, such as influential authors/institutions, hot topics, and future trends. Scholars enable to understand the development of the CACAIE, and grasp some opinions after analysing.

\section{Conclusions}

In this article, we make an overview of an outstanding journal CACAIE based on bibliometric analysis from 2000 to 2019. With the help of bibliometric methods and tools (VOSviewer and CiteSpace), characteristics of publications in WoS are presented. More specifically, fundamental information of publications is explored including types, the NP, citations and $h$-index every year. Then, we analyse that who pays closer attention to the journal and what the journal most focuses on from multiple aspects, i.e., sources, countries/regions, institutions and authors. The influential countries/regions and references are presented, and collaboration networks are given at the levels of countries/regions, institutions and authors. In addition, the development trends and hot topics are conducted by co-occurrence analysis and timeline view of keywords. Considering that CACAIE refers to four fields, we summarize researches in publications in relevant fields, i.e., Construction \& Building Technology; Engineering, Civil; Transportation Science \& Technology; and Computer Science, Interdisciplinary Applications. Furthermore, we make some discussions for the journal and scholars who are interested in these fields. According to the above-mentioned analysis, some main findings are concluded as follows:

- CACAIE is an influential international journal, because the NC has shown a steady upward trend over 20 years, and most top journals have paid closer attention to it.

- the US is the most prolific and influential country because of the highest NP and NC. California Institute of Technology (US) ranks the first in terms of total link strength, followed by University of Illinois Urbana-Champaign (US), Hong Kong University of Science and Technology (China), Tongji University (China) and Harbin Institute of Technology (China). H. Adeli is the most recognized author, and E. Castillo is the leading author as for the total link strength.

- After analysing high-cited publications in CACAIE, methods based on deep learning algorithms have been more popular for scholars to deal with practical applications because of better performance and higher effective. 
The results give a certain reference for scholars and journals to further study relevant fields and promote the scientific-technological progress. In addition, the timeline view of keywords and discussions could help people who are interested in CACAIE to grasp hot points and inspire some ideas. In the future, we will further focus on the development of the journal, and study advance technologies related to bibliometric analysis.

\section{Acknowledgements}

The work was supported by:

- the National Natural Science Foundation of China (Grants No 71571123, 71771155);

- the Opening Project of Sichuan Province University Key Laboratory of Bridge Non-destruction Detecting and Engineering Computing (Grant No 2019QYJ03);

- the Fundamental Research Funds for the Central Universities (Grant No YJ202063).

\section{References}

Adeli, H. 2001. Neural networks in civil engineering: 1989-2000, Computer-Aided Civil and Infrastructure Engineering 16(2): 126-142. https://doi.org/10.1111/0885-9507.00219

Adeli, H.; Jiang, X. 2006. Dynamic fuzzy wavelet neural network model for structural system identification, Journal of Structural Engineering 132(1): 102-111. https://doi.org/10.1061/(ASCE)0733-9445(2006)132:1(102)

Adeli, H.; Jiang, X. 2009. Intelligent Infrastructure: Neural Networks, Wavelets, and Chaos Theory for Intelligent Transportation Systems and Smart Structures. CRC Press. 440 p. https://doi.org/10.1201/9781482281767

Adeli, H.; Kumar, S. 1995. Distributed genetic algorithm for structural optimization, Journal of Aerospace Engineering 8(3): 156-163. https://doi.org/10.1061/(ASCE)0893-1321(1995)8:3(156)

Amézquita-Sánchez, J. P.; Adeli, H. 2016. Signal processing techniques for vibration-based health monitoring of smart structures, Archives of Computational Methods in Engineering 23(1): 1-15. https://doi.org/10.1007/s11831-014-9135-7

Azevedo, S. G.; Santos, M.; Rodríguez-Antón, J. 2019. Supply chain of renewable energy: a bibliometric review approach, Biomass and Bioenergy 126: 70-83.

https://doi.org/10.1016/j.biombioe.2019.04.022

Cha, Y.-J.; Büyüköztürk, O. 2015. Structural damage detection using modal strain energy and hybrid multiobjective optimization, Computer-Aided Civil and Infrastructure Engineering 30(5): 347-358. https://doi.org/10.1111/mice.12122

Cha, Y.-J.; Choi, W.; Büyüköztürk, O. 2017. Deep learning-based crack damage detection using convolutional neural networks, Computer-Aided Civil and Infrastructure Engineering 32(5): 361-378. https://doi.org/10.1111/mice.12263

Cha, Y.-J.; Choi, W.; Suh, G.; Mahmoudkhani, S.; Büyüköztürk, O. 2018. Autonomous structural visual inspection using regionbased deep learning for detecting multiple damage types, Computer-Aided Civil and Infrastructure Engineering 33(9): 731-747. https://doi.org/10.1111/mice.12334

Chan, T. M.; Kuehl, D. R. 2019. On lampposts, sneetches, and stars: a call to go beyond bibliometrics for determining academic value, Academic Emergency Medicine 26(6): 688-694. https://doi.org/10.1111/acem.13707

Chen, C. 2006. CiteSpace II: detecting and visualizing emerging trends and transient patterns in scientific literature, Journal of the American Society for Information Science and Technology 57(3): 359-377. https://doi.org/10.1002/asi.20317
Chen, X.; Liu, Y. 2020. Visualization analysis of high-speed railway research based on CiteSpace, Transport Policy 85: 1-17. https://doi.org/10.1016/j.tranpol.2019.10.004

Cobo, M. J.; López-Herrera, A. G.; Herrera-Viedma, E.; Herrera, F. 2011. Science mapping software tools: review, analysis, and cooperative study among tools, Journal of the American Society for Information Science and Technology 62(7): 1382-1402. https://doi.org/10.1002/asi.21525

Falagas, M. E.; Pitsouni, E. I.; Malietzis, G. A.; Pappas, G. 2008. Comparison of PubMed, Scopus, Web of Science, and Google Scholar: strengths and weaknesses, The FASEB Journal 22(2): 338-342. https://doi.org/10.1096/fi.07-9492LSF

Gao, Y.; Mosalam, K. M. 2018. Deep transfer learning for imagebased structural damage recognition, Computer-Aided Civil and Infrastructure Engineering 33(9): 748-768. https://doi.org/10.1111/mice.12363

Hache, E.; Palle, A. 2019. Renewable energy source integration into power networks, research trends and policy implications: a bibliometric and research actors survey analysis, Energy Policy 124: 23-35. https://doi.org/10.1016/j.enpol.2018.09.036

He, X.; Wu, Y.; Yu, D.; Merigó, J. 2017. Exploring the ordered weighted averaging operator knowledge domain: a bibliometric analysis, International Journal of Intelligent Systems 32(11): 1151-1166. https://doi.org/10.1002/int.21894

Hsieh, P.-N.; Chang, P.-L. 2009. An assessment of world-wide research productivity in production and operations management, International Journal of Production Economics 120(2): 540-551. https://doi.org/10.1016/j.ijpe.2009.03.015

Jafarkhani, R.; Masri, S. F. 2011. Finite element model updating using evolutionary strategy for damage detection, ComputerAided Civil and Infrastructure Engineering 26(3): 207-224. https://doi.org/10.1111/j.1467-8667.2010.00687.x

Jiang, X.; Adeli, H. 2008. Dynamic fuzzy wavelet neuroemulator for non-linear control of irregular building structures, International Journal for Numerical Methods in Engineering 74(7): 1045-1066. https://doi.org/10.1002/nme.2195

Jiang, X.; Adeli, H. 2005a. Dynamic wavelet neural network for nonlinear identification of highrise buildings, ComputerAided Civil and Infrastructure Engineering 20(5): 316-330. https://doi.org/10.1111/j.1467-8667.2005.00399.x

Jiang, X.; Adeli, H. 2005b. Dynamic wavelet neural network model for traffic flow forecasting, Journal of Transportation Engineering 131(10): 771-779.

https://doi.org/10.1061/(ASCE)0733-947X(2005)131:10(771)

Jiang, X.; Adeli, H. 2008. Neuro-genetic algorithm for non-linear active control of structures, International Journal for Numerical Methods in Engineering 75(7): 770-786.

https://doi.org/10.1002/nme.2274

Jiang, X.; Adeli, H. 2007. Pseudospectra, MUSIC, and dynamic wavelet neural network for damage detection of highrise buildings, International Journal for Numerical Methods in Engineering 71(5): 606-629. https://doi.org/10.1002/nme.1964

Jiang, X.; Adeli, H. 2004. Wavelet packet-autocorrelation function method for traffic flow pattern analysis, Computer-Aided Civil and Infrastructure Engineering 19(5): 324-337. https://doi.org/10.1111/j.1467-8667.2004.00360.x

Jiang, X.; Mahadevan, S. 2008. Bayesian wavelet methodology for structural damage detection, Structural Control and Health Monitoring 15(7): 974-991. https://doi.org/10.1002/stc.230

Kamdem, J. P.; Duarte, A. E.; Lima, K. R. R.; Rocha, J. B. T.; Hassan, W.; Barros, L. M.; Roeder, T.; Tsopmo, A. 2019. Research trends in Food Chemistry: a bibliometric review of its 40 years anniversary (1976-2016) (1976-2016), Food Chemistry 294: 448-457. https://doi.org/10.1016/j.foodchem.2019.05.021 
Kijewski, T.; Kareem, A. 2003. Wavelet transforms for system identification in civil engineering, Computer-Aided Civil and Infrastructure Engineering 18(5): 339-355.

https://doi.org/10.1111/1467-8667.t01-1-00312

Kuzhel, N.; Bieliatynskyi, A.; Prentkovskis, O.; Klymenko, I.; Mikaliūnas, Š.; Kolganova, O.; Kornienko, S.; Shutko, V. 2013. Methods for numerical calculation of parameters pertaining to the microscopic following-the-leader model of traffic flow: using the fast spline transformation, Transport 28(4): 413419. https://doi.org/10.3846/16484142.2013.868369

Laengle, S.; Merigó, J. M.; Miranda, J.; Słowiński, R.; Bomze, I.; Borgonovo, E.; Dyson, R. G.; Oliveira, J. F.; Teunter, R. 2017. Forty years of the European Journal of Operational Research: a bibliometric overview, European Journal of Operational Research 262(3): 803-816.

https://doi.org/10.1016/j.ejor.2017.04.027

Lin, Y.-Z.; Nie, Z.-H.; Ma, H.-W. 2017. Structural damage detection with automatic feature-extraction through deep learning, Computer-Aided Civil and Infrastructure Engineering 32(12): 1025-1046. https://doi.org/10.1111/mice.12313

Marano, G. C.; Quaranta, G.; Monti, G. 2011. Modified genetic algorithm for the dynamic identification of structural systems using incomplete measurements, Computer-Aided Civil and Infrastructure Engineering 26(2): 92-110. https://doi.org/10.1111/j.1467-8667.2010.00659.x

Mardani, A.; Zavadskas, E. K.; Khalifah, Z.; Jusoh, A.; Nor, K. 2016. Multiple criteria decision-making techniques in transportation systems: a systematic review of the state of the art literature, Transport 31(3): 359-385.

https://doi.org/10.3846/16484142.2015.1121517

Opricovic, S.; Tzeng, G.-H. 2002. Multicriteria planning of postearthquake sustainable reconstruction, Computer-Aided Civil and Infrastructure Engineering 17(3): 211-220. https://doi.org/10.1111/1467-8667.00269

Park, H. S.; Lee, H. M.; Adeli, H.; Lee, I. 2007. A new approach for health monitoring of structures: terrestrial laser scanning, Computer-Aided Civil and Infrastructure Engineering 22(1): 19-30. https://doi.org/10.1111/j.1467-8667.2006.00466.x

Pilkington, A.; Meredith, J. 2009. The evolution of the intellectual structure of operations management - 1980-2006: a citation/ co-citation analysis, Journal of Operations Management 27(3): 185-202. https://doi.org/10.1016/j.jom.2008.08.001

Prentkovskis, O.; Sokolovskij, E.; Bartulis, V. 2010. Investigating traffic accidents: a collision of two motor vehicles, Transport 25(2): 105-115. https://doi.org/10.3846/transport.2010.14

Sarma, K. C.; Adeli, H. 2001. Bilevel parallel genetic algorithms for optimization of large steel structures, Computer-Aided Civil and Infrastructure Engineering 16(5): 295-304. https://doi.org/10.1111/0885-9507.00234

Shang, G.; Saladin, B.; Fry, T.; Donohue, J. 2015. Twenty-six years of operations management research (1985-2010): authorship patterns and research constituents in eleven top rated journals, International Journal of Production Research 53(20): 6161-6197. https://doi.org/10.1080/00207543.2015.1037935

Sokolovskij, E. 2007. Computer modeling of the process of overturning of the automobile, Transport 22(1): 19-23. https://doi.org/10.3846/16484142.2007.9638090

Stopar, K.; Bartol, T. 2019. Digital competences, computer skills and information literacy in secondary education: mapping and visualization of trends and concepts, Scientometrics 118(2): 479-498. https://doi.org/10.1007/s11192-018-2990-5

Ukkusuri, S. V.; Mathew, T. V.; Waller, S. T. 2007. Robust transportation network design under demand uncertainty, Computer-Aided Civil and Infrastructure Engineering 22(1): 6-18. https://doi.org/10.1111/j.1467-8667.2006.00465.x

Wang, C.; Liu, Z.; Gao H.; Fu Y. 2019. VOS: A new outlier detec- tion model using virtual graph, Knowledge-Based Systems 185: 104907. https://doi.org/10.1016/j.knosys.2019.104907

Wang, X.; Xu, Z.; Su, S.-F.; Zhou, W. 2021. A comprehensive bibliometric analysis of uncertain group decision making from 1980 to 2019, Information Sciences 547: 328-353. https://doi.org/10.1016/j.ins.2020.08.036

White, H. D. 2018. Pennants for Garfield: bibliometrics and document retrieval, Scientometrics 114(2): 757-778. https://doi.org/10.1007/s11192-017-2610-9

Xue, Y.; Li, Y. 2018. A fast detection method via region-based fully convolutional neural networks for shield tunnel lining defects, Computer-Aided Civil and Infrastructure Engineering 33(8): 638-654. https://doi.org/10.1111/mice.12367

Yang, X. C.; Li, H.; Yu, Y.; Luo, X.; Huang, T.; Yang, X. 2018. Automatic pixel-level crack detection and measurement using fully convolutional network, Computer-Aided Civil and Infrastructure Engineering 33(12): 1090-1109. https://doi.org/10.1111/mice.12412

Yao, B.; Chen, C.; Cao, Q.; Jin, L.; Zhang, M.; Zhu, H.; Yu, B. 2017. Short-term traffic speed prediction for an urban corridor, Computer-Aided Civil and Infrastructure Engineering 32(2): 154-169. https://doi.org/10.1111/mice.12221

Yeum, C. M.; Dyke, S. J. 2015. Vision-based automated crack detection for bridge inspection, Computer-Aided Civil and Infrastructure Engineering 30(10): 759-770.

https://doi.org/10.1111/mice.12141

Yu, D.; Xu, Z.; Antuchevičienè, J. 2019. Bibliometric analysis of the Journal of Civil Engineering and Management between 2008 and 2018, Journal of Civil Engineering and Management 25(5): 402-410. https://doi.org/10.3846/jcem.2019.9925

Yu, D.; Xu, Z.; Kao, Y.; Lin, C.-T. 2018. The Structure and Citation Landscape of IEEE Transactions on Fuzzy Systems (19942015), IEEE Transactions on Fuzzy Systems 26(2): 430-442. https://doi.org/10.1109/TFUZZ.2017.2672732

Yu, D.; Xu, Z.; Pedrycz, W.; Wang, W. 2017. Information Sciences 1968-2016: a retrospective analysis with text mining and bibliometric, Information Sciences 418-419: 619-634. https://doi.org/10.1016/j.ins.2017.08.031

Yuen, K.-V.; Mu, H.-Q. 2015. Real-time system identification: an algorithm for simultaneous model class selection and parametric identification, Computer-Aided Civil and Infrastructure Engineering 30(10): 785-801.

https://doi.org/10.1111/mice.12146

Zagorskas, J.; Turskis, Z. 2020. Setting priority list for construction works of bicycle path segments based on Eckenrode rating and ARAS-F decision support method integrated in GIS, Transport 35(2): 179-192. https://doi.org/10.3846/transport.2020.12478

Zavadskas, E. K. 2020. An exemplary journal and its impact on other journals, Computer-Aided Civil and Infrastructure Engineering 35(8): 773-774. https://doi.org/10.1111/mice.12597

Zhang, A.; Wang, K. C. P.; Li, B.; Yang, E.; Dai, X.; Peng, Y.; Fei, Y.; Liu, Y.; Li, J. Q.; Chen, C. 2017. Automated pixel-level pavement crack detection on $3 \mathrm{D}$ asphalt surfaces using a deep-learning network, Computer-Aided Civil and Infrastructure Engineering 32(10): 805-819. https://doi.org/10.1111/mice.12297

Zhou, W.; Xu, Z.; Skačkauskas, P. 2019. Mapping knowledge domain of "TRANSPORT": a bibliometric study of its status quo and emerging trends, Transport 34(6): 741-753. https://doi.org/10.3846/transport.2019.11774

Zhou, W.; Xu, Z.; Zavadskas, E. K.; Laurinavičius, A. 2020. The knowledge domain of The Baltic Journal of Road and Bridge Engineering between 2006 and 2019, The Baltic Journal of Road and Bridge Engineering 15(2): 1-30. https://doi.org/10.7250/bjrbe.2020-15.470 